University of Rhode Island

DigitalCommons@URI

Open Access Master's Theses

1991

\title{
A GOLF COURSE FEASIBILITY STUDY FOR BLOCK ISLAND
}

James F. Moran

University of Rhode Island

Follow this and additional works at: https://digitalcommons.uri.edu/theses

Recommended Citation

Moran, James F., "A GOLF COURSE FEASIBILITY STUDY FOR BLOCK ISLAND" (1991). Open Access

Master's Theses. Paper 563.

https://digitalcommons.uri.edu/theses/563

This Thesis is brought to you for free and open access by DigitalCommons@URI. It has been accepted for inclusion in Open Access Master's Theses by an authorized administrator of DigitalCommons@URI. For more information, please contact digitalcommons@etal.uri.edu. 


\title{
A GOLF COURSE FEASIBILITY \\ STUDY FOR BLOCK ISLAND
}

BY

JAMES F. MORAN

\author{
A RESEARCH PROJECT SUBMITTED IN \\ PARTIAL FULFILLMENT OF THE REQUIREMENTS \\ FOR THE DEGREE OF MASTER OF \\ COMMUNITY PLANNING
}

UNIVERSITY OF RHODE ISLAND

SPRING 1991 


\section{MASTER OF COMMUNITY PLANNING \\ RESEARCH PROJECT \\ OF}

JAMES F. MORAN

Approved:

Major Professor: Dr. Farhad Atash

Acknowledged:

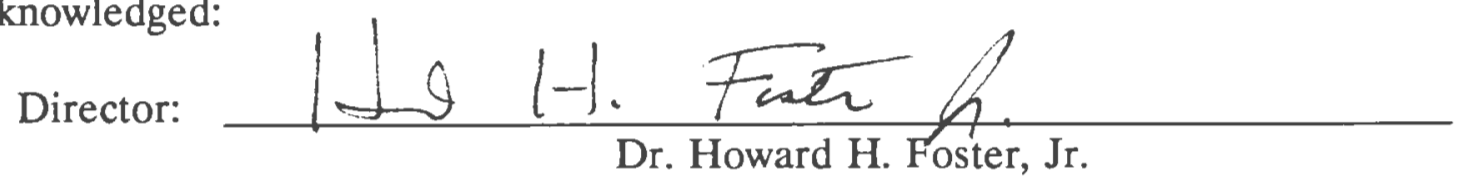




\section{ACKNOWLEDGEMENTS}

There are several people I wish to thank for their help in completing this project. First, Mr. Mark Emmanuelle, of the Block Island Golf Course Study Committee, whose cheerful assistance in all phases of this project made data collection a much simpler process. His assistance has been greatly appreciated. Second, I would like to thank Mr. Michael Weremay, of Gates, Leighton and Associates, Inc. His assistance during site walks provided valuable information regarding regulatory and environmental constraints.

I am especially thankful to my advisor, Dr. Farhad Atash. His advice was instrumental in the development and format of the entire project. Dr. John Kupa is also due many thanks for his helpful comments and suggestions.

Much appreciation is extended to my family for giving me the support and encouragement I needed when making the difficult decision to leave the working world and return to school.

Finally, I would like to extend my warmest thanks to my wife Virginia, whose incredible support and patience during my tenure as a student will always be remembered and appreciated. 


\section{TABLE OF CONTENTS}

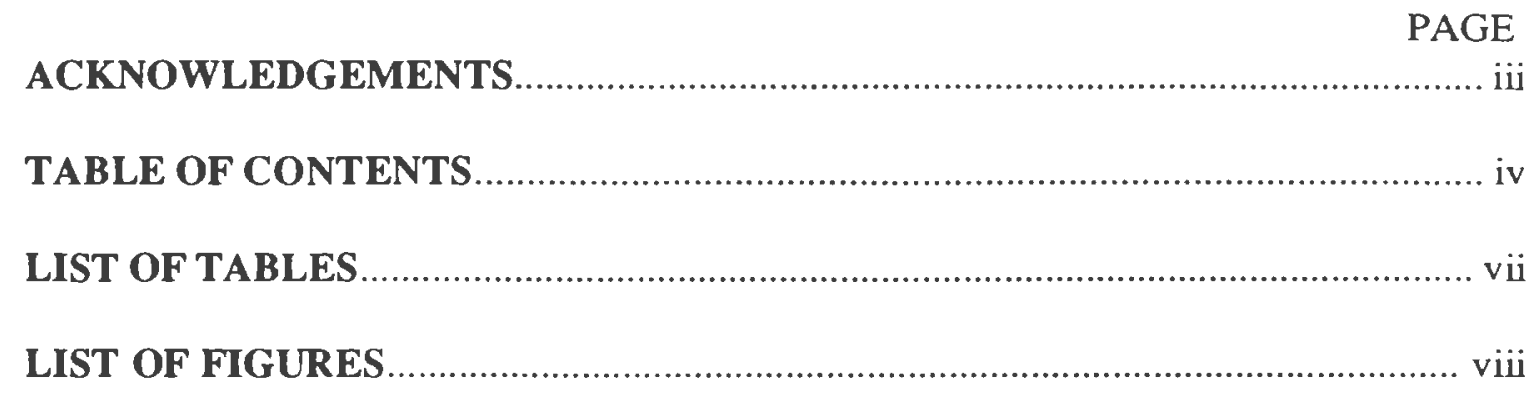

CHAPTER ONE INTRODUCTION ............................................................... 1

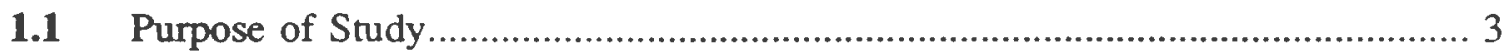

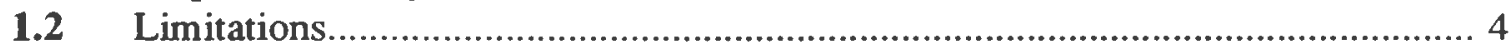

1.2.1 Demographics and Tourist Counts................................................................ 4

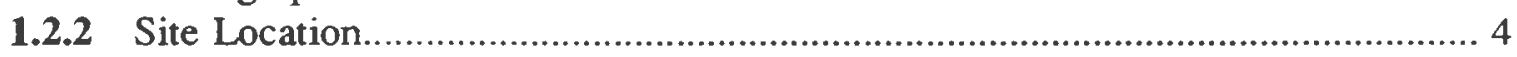

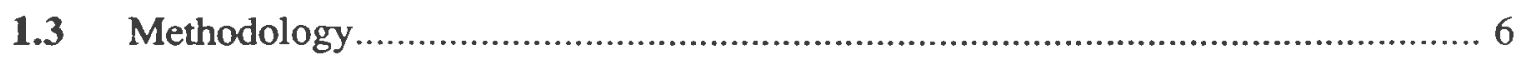

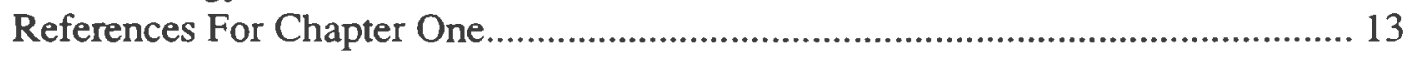

CHAPTER TWO PROFILE OF ISLAND AND SITE DESIGNATIONS........... 14

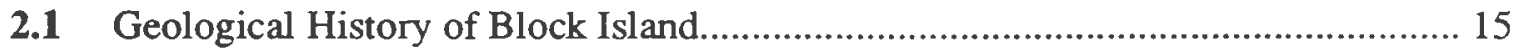

2.2 History and Social Culture of Island............................................................ 16

2.2.1 Block Island's Original Golf Course........................................................... 19

2.3 Site Descriptions and Delineations................................................................ 20

2.3.1 Northem Site: Site Description and Acquisition Possibilities............................ 22

2.3.2 Southem Site: Site Description and Acquisition Possibilities........................... 26

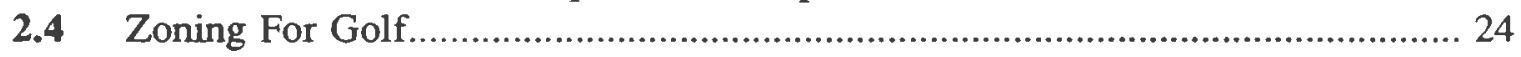

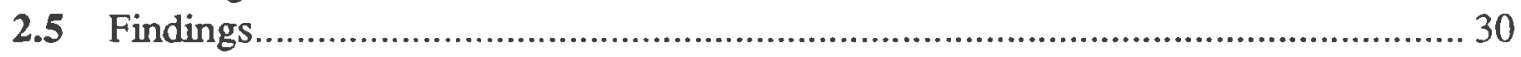

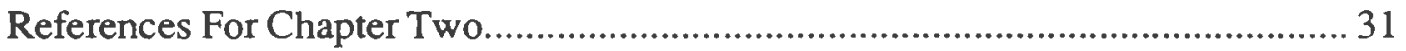

CHAPTER THREE GOLF COURSE NEEDS ASSESSMENT ............................. 32

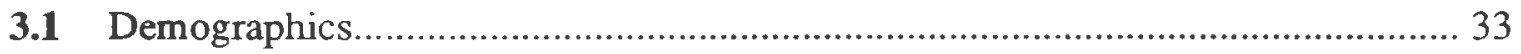

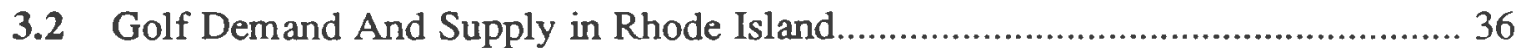

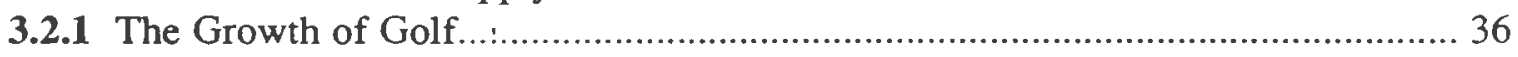

3.2.2 Rhode Island Golf Demand Analysis........................................................... 37

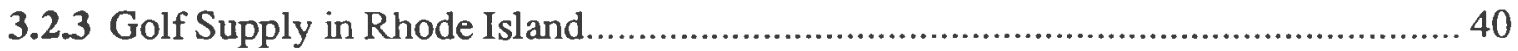


3.2.4 Supply vs. Demand.

3.2.5 Block Island Golf Demand and Supply................................................... 42

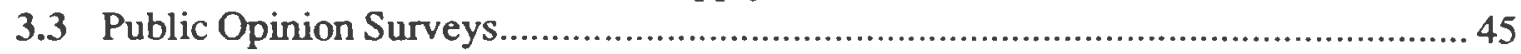

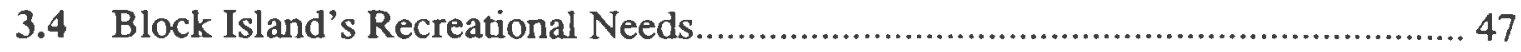

3.5 Open Space Preservation................................................................................ 47

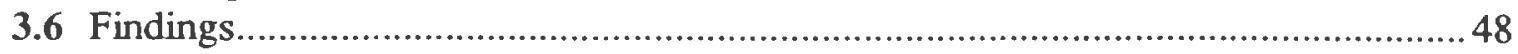

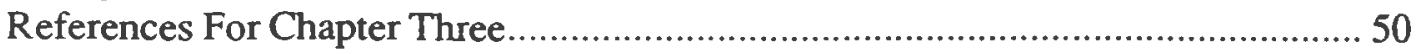

CHAPTER FOUR ENVIRONMENTAL ASSESSMENT ................................. 51

4.1 Golf Course Design: "The Links Course"..................................................... 52

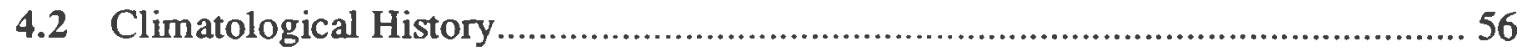

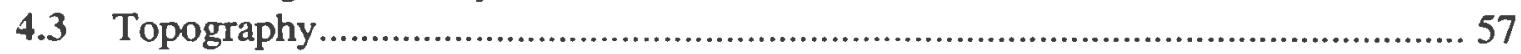

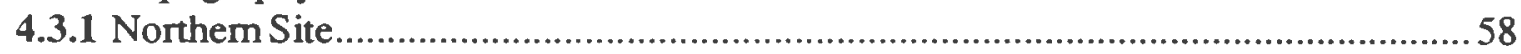

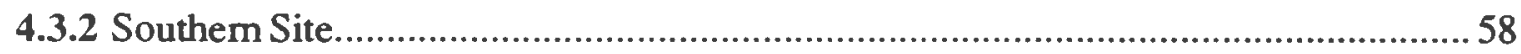

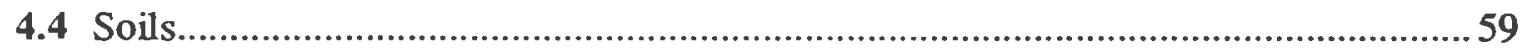

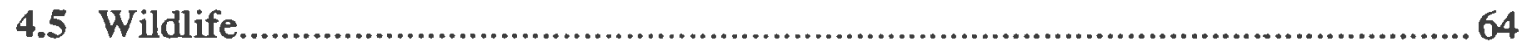

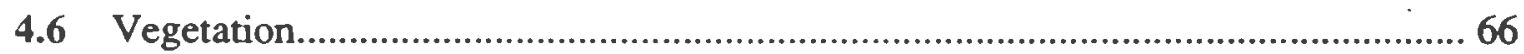

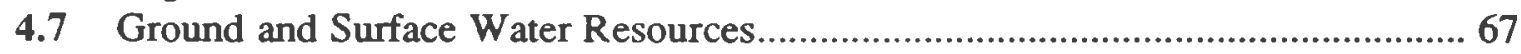

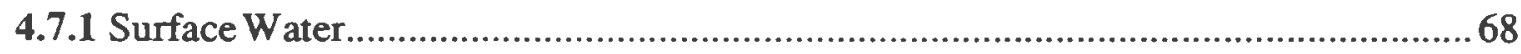

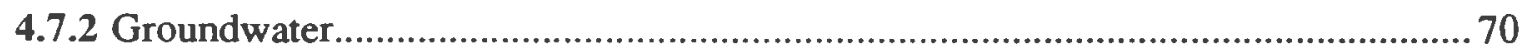

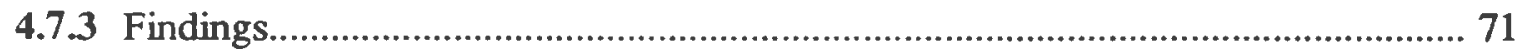

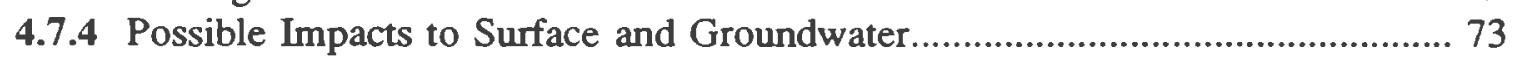

4.7.5 Fertilizer Requirements for the Golf Course .................................................. 75

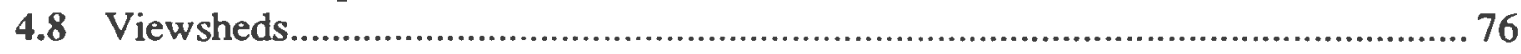

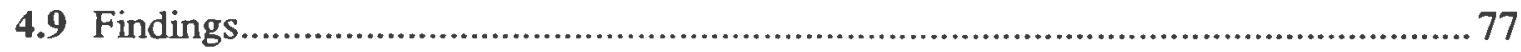

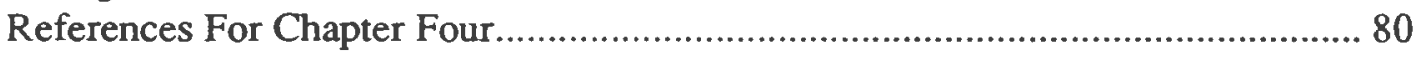

CHAPTER FIVE FINANCIAL ASSESSMENT ............................................ 81

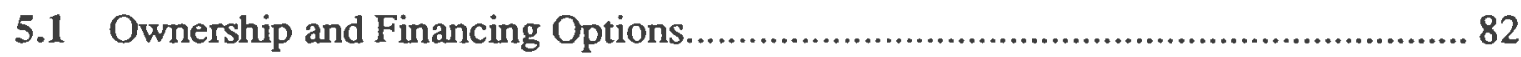

5.2 Nantucket's "Links" Golf Course ................................................................ 85

5.3 Golf Course Cost Estimates....................................................................... 87

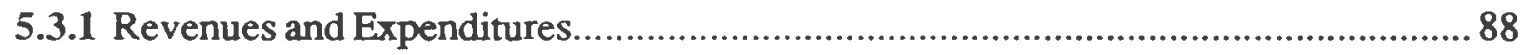

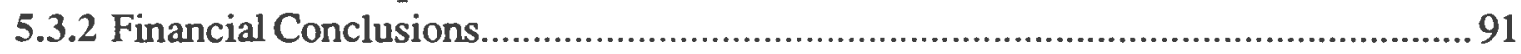

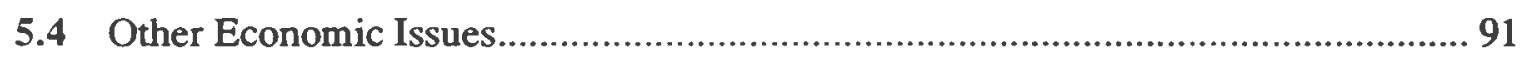

5.4.1 Attracting Golf Tourism to Block Island.................................................. 91

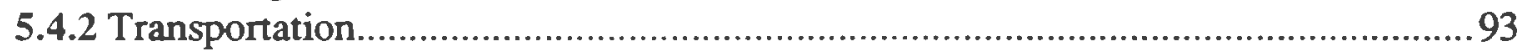

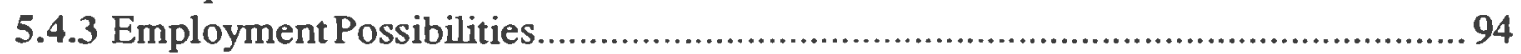

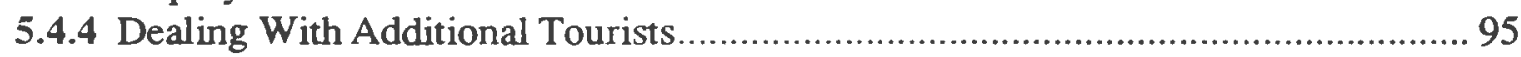

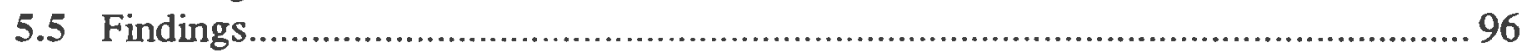

References For Chapter Five.................................................................. 98 
APPENDIX A Block Island Golf Course Study Committee Survey Results............. 100

APPENDIX B Golf Courses Contacted For Demand Analysis............................... 105

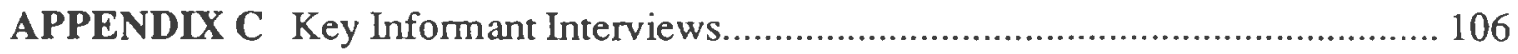




\section{LIST OF TABLES}

PAGE

1. Estimated Number of Tourists By Type and Total Tourist Days............................. 35

2. Average Monthly Temperatures, Block Island, Rhode Island, 1969-1989.................57

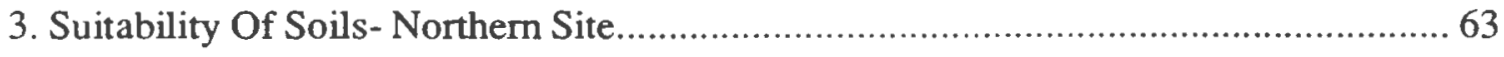

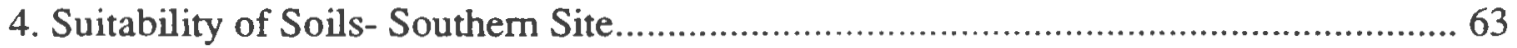

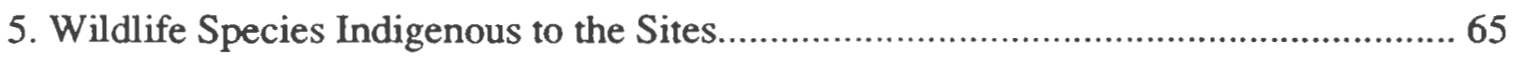

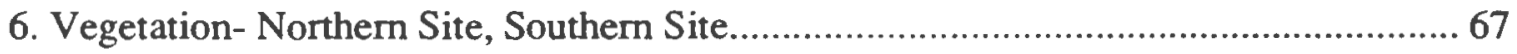

7. Typical Yearly Nitrogen Fertilizer Program For Golf Courses................................ 75

8. Grasses Suitable For Use on Links Fairways and Roughs.................................... 76

9. Cost Estimate For Block Island Golf Course Development.................................. 89

10. Projected Revenues and Expenditures For Block Island Golf Course......................90 


\section{LIST OF FIGURES}

PAGE

1. Location of Proposed Northern and Southem Golf Sites....................................... 21

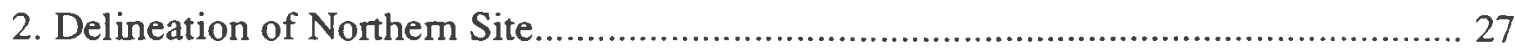

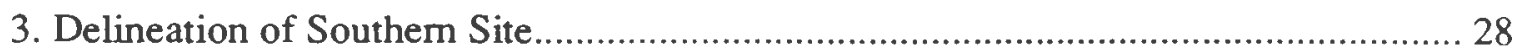

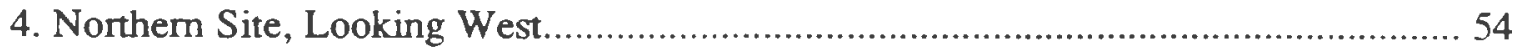

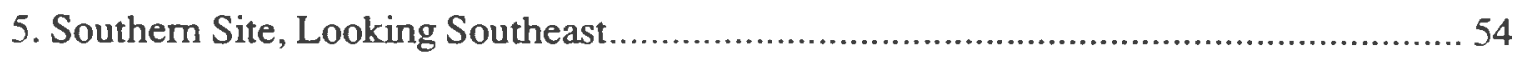

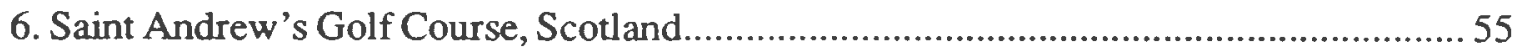

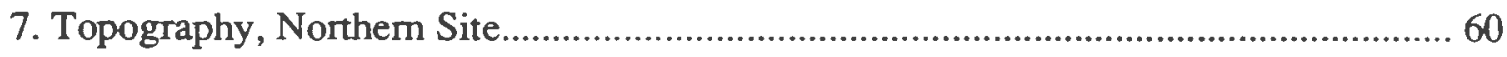

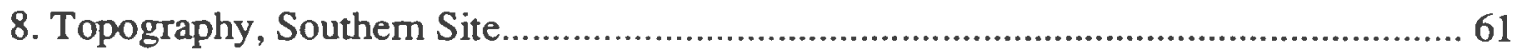

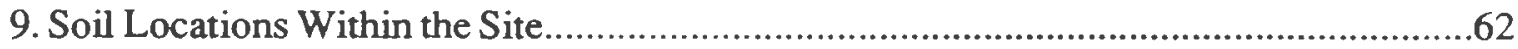

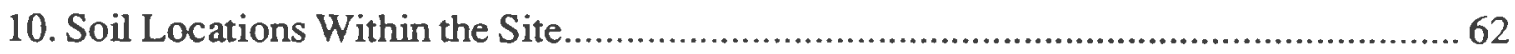

11 Groundwater Resource Availability, Northem Site.............................................. 72

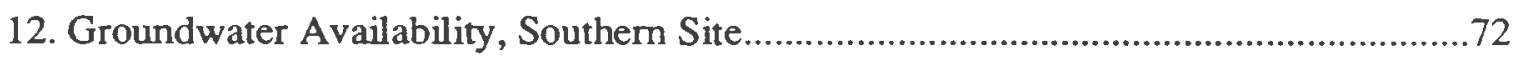

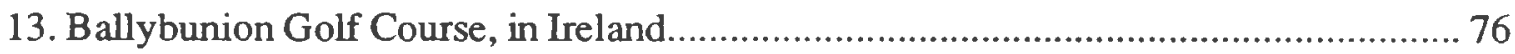

14. Newspaper Advertisement promoting a Cape Cod golf Facility............................ 92 


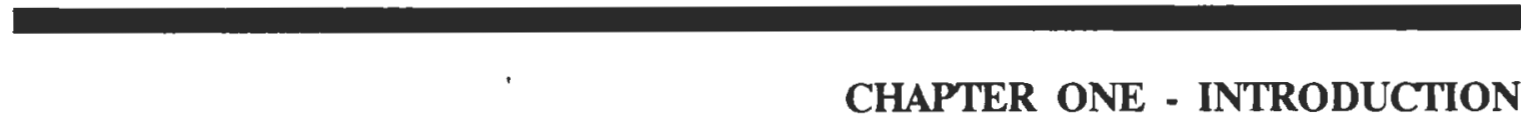


The Town of New Shoreham has expressed its desire to improve its economic base through diversification (Comprehensive Plan Citizens Participation Workshop, November, 1990). A golf course was one of the options which the town had expressed an interest in. Interest has grown to the point where a golf course study committee has been formed to assess the need for golf on Block Island.

Golf is one of the nations most popular forms of recreation (National Golf Foundation, 1989). Over the past ten years, the sport has seen great advances in the number of individuals who play the game. It is a form of recreation that is appropriate for all ages, from the young to the very old. Studies by the National Golf Foundation (NGF) have provided information that shows this growth continuing well into the 21st century. Based on current growth, the NGF statistics show that nationally, the number of golfers entering the sport are far outpacing the number of golf courses being developed. This is the case for Rhode Island as well. There is no doubt from these amassed statistics, that there will be a need for more golf courses in the future to provide additional golf destinations to the already existing overburdened golf courses in the region.

Simply making this statement is not enough. Significant monetary commitments are required in the development of a course; therefore an accurate assessment of demand, supply, market analysis, environmental and social elements must be closely examined to determine if a course would indeed be a profitable venture for Block Island.

A golf course has the potential to provide new income for the Town either in the 
form of tax revenues if the golf course were purchased and managed by a private group, or through revenues generated from the course operation itself if the course were owned and managed by the town itself. In addition, open space land could be preserved while at the same time providing employment for the residents of the Town.

\subsection{Purpose of This Study}

The purpose of this study will be to assess the profit potential for a golf course on Block Island. It will also examine how a golf course would impact the social, cultural and environmental elements of the island. A broad range of analyses will be required to determine this feasibility. A previous study conducted by The University of Rhode Island Advanced Planning Studio at The Department of Community Planning and Area Development addressed golf implementation and general feasibility, but did not delve into examining the specific sites, the environmental issues, as well as demographic studies, demand and supply analysis (needs assessment) and other various economic and social conditions. This project will examine in greater detail, these as well as other important issues that may play a strong part in determining whether a course could be a profitable, sound venture that would expand the Island's tourist economy and protect environmental and cultural integrity on Block Island. 


\subsection{LIMITATIONS}

\subsubsection{Demographics and Tourist Counts}

The study encountered some difficulty in determining the number of tourists who come to the Island by ferry during the busy summer months. The Interstate Navigation Service (this company provides ferry service to the island from Narragansett and New London, Connecticut) provide figures for the amount of people arriving by the ferry service. The Town, however, feels these numbers are inaccurate and that the actual number of tourists arriving is far greater. The town has its own statistics and in addition, a tourist count study conducted by Tim Tyrell and Pat Manheim of the University of Rhode Island may prove to be more accurate in determining more precise numbers. Because they are widely considered to be the most accurate, Tyrell's and Manheim's statistics will be used in this study.

Inquiries received by the Chamber of Commerce will be used to determine which states the tourists are coming from. Since these are inquiries, the actual number of people arriving from these states may not exactly coincide with the inquiry figures.

\subsubsection{Site Location}

The Block Island Golf Course Study Committee (BIGCSC) has designated two areas on the Island that show some promise for golf development. This report will examine these two areas in detail. It must be stated however, that many parcels are privately owned and there are an infinite number of acquisition possibilities available. Certain parcels may be well suited for golf but may be unavailable if the owner of 
the property is not interested in the golf concept. Site acquisition may be a limitation to golf development on these sites. This study then, will examine the feasibility of these sites for golf development but will make certain to stipulate that a variety of acquisition possibilities exist and until these are resolved, land acquisition could prove to be the primary limitation of the study.

A final limitation that is somewhat unique in terms of Block Island and its relation to other courses in Rhode Island, is its isolation. On mainland courses, designating a market area is simply a matter of drawing a circle of a determined radius around the intended site location. This area becomes the study area and it is more simple to make determinations regarding supply, demand, etc. On Block Island, it becomes necessary to make assumptions as to how an island will fare in attracting golfers to the Island from the mainland. The relationship between the Island and the mainland market is more difficult to quantify due to this isolation factor. A golf course on the Island would be isolated from its competition, and hence it would be more difficult to assess if it could successfully compete with courses on the mainland. Although Block Island is a tourist destination that would probably tend to attract a large group of individuals who would be interested in playing golf, this Island isolation factor must still be considered a limitation of the study. 


\subsection{METHODOLOGY}

The following methodology will be utilized in the development of this feasibility study:

\section{PROFILE OF ISLAND AND SITE DESIGNATIONS}

The study will begin with the geological history of the Island, highlighting its development and general geological characteristics. The study will also include a brief history of the Island in order to familiarize the reader with the human and social development of Block Island. Such an overview will help provide credibility to the concept that economic diversity is important to the fiscal health of the community in the future.

History may prove useful in determining golf feasibility on Block Island. The Island at one time had a golf course on its Southern shoreline. This study will research this golf course to determine how it developed and more importantly why it failed. By determining why the course did not succeed, it may help in addressing feasibility for a future course. With these basics addressed, the major research sections of the study will be covered.

\section{Site Descriptions and Delineations}

This section of the study will describe and delineate the two sites designated by the BIGCSC. One site is located on the northern portion of the Island and the other to on the southern side. With the use of maps and narrative the boundaries of the sites will be described. This section will also examine zoning of the sites, current 
owners of the parcels under consideration, and possible CRMC regulations that may have an effect on the development of the project.

\section{Zoning For Golf}

The zoning regulations of a community play an important role in golf development. Proper zoning requirements need to be in place before the course can be proposed. This section will examine zoning requirements of communities who have golf related zoning requirements in place. This section will also examine any regulations within Block Island's ordinance that deal with golf course development. Innovative zoning requirements from other communities could be incorporated into Block Island's zoning regulations so that when development does occur the town will have proper zoning requirements in place.

\section{NEEDS ASSESSMENT}

\section{Demographics}

This element of the report will determine the number of residents living on the Island, since a certain element of these residents would be golfers, but more importantly this section will attempt to determine the number of tourists who come to the Island, since this group would probably be the largest group to use a golf course, especially during the busy summer months. The method that will be used to determine this information will include:

1. Using both 1980 and 1990 US Census data will furnish the total population of 
permanent residents on the Island, employment data, average income, etc.

2. Tourism counts provided by a study conducted by Tim Tyrell and Pat Manheim of the University of Rhode Island. This study will provide the best estimates of tourists arriving on the Island during the summer months.

3. The Block Island Chamber of Commerce has compiled data concerning vacation inquiries for tourists from other states. Although this data may not be entirely accurate it can provide estimates regarding where the tourists arriving on the Island come from.

\section{Golf Demand And Supply}

The National Golf Foundation (NGF) provide information concerning golf supply, demand and other golf related statistics. Using NGF studies in conjunction with local and other demographic studies it will be possible to determine roughly how many of the arriving tourists are potential golfers. It will also provide basic information pertaining to the number of individuals who play golf in the Northeast and more specifically Rhode Island.

Other elements that will be utilized to determine the need for a golf course on Block Island will inclúde:

1. Local and regional study of economic conditions will be studied to help determine if conditions could impact golf development in the future.

2. As mentioned earlier, NGF studies help determine the direction of golf. These 
studies can help deduce if a golf facility would be an economic success for the Island.

3. Some articles have recommended caution when considering a golf course. Recent articles in Forbes Magazine and The Providence Business News have stated that there may be changes in golf demand. These comments must all be weighed carefully in determining golf feasibility.

4. Primary data will be collected to help determine the number of rounds of golf played on other courses in the region. This will help determine more accurately if golf demand is high in the area. Other examples of primary data collection include:

a. Survey of inn and hotel managers on Block Island questioning their opinions of golf development on the Island.

b. Non-scientific survey of golf courses in Southern Rhode Island in order to determine the number of rounds played on the courses per year, average wait for tee time, and other question relevant in determining if courses are generally overcrowded.

The above criteria combined will constitute a market survey that will help determine profitability in golf development.

Attitude surveys play an important role in helping to determine feasibility. The Block Island Golf Course Study Committee Survey will help assess public support for such a venture. Without public support implementation of such a proposal would become more difficult. 


\section{ENVIRONMENTAL ASSESSMENT}

\section{Golf Course Design Possibilities}

This section will briefly state some of the designs that are currently being used in course development. After examining design styles, it will be possible to determine which course design could have the best potential for providing economic, environmental and cultural benefit to the Island.

The environmental assessment will continue with a detailed climatological history of the Island from 1969 to 1989 . This will prove useful in determining the possible length of the golf playing season, which is important from an economic standpoint as well.

Due to the fact that two location possibilities exist, each area will be examined in detail individually. The sites will be evaluated under the following criteria:

1. Topography- Showing ten foot intervals. Constraints relative to slope will be assessed.

2. Soils- All soil types encountered will be assessed to determine their suitability to golf.

3. Wildlife- A wide variety of animal life can be found on Block Island. Through primary (site walks) and secondary data collection, all wildlife encountered on the sites will be documented. Any endangered species on the site will be noted.

4. Vegetation- Similarly, all vegetation will be documented on the sites using primary and secondary data.

5. Groundwater- This element plays an important part in the assessment. 
Groundwater resources will be examined in detail. Areas of concern include nutrient loading by fertilizers and pesticides, sodium concentrations, and quantities available for irrigation and drinking purposes.

6. Surface Water- This hydrologic element is also very important since many of these areas are associated with freshwater wetlands. The waterbodies will be assessed using similar criteria for groundwater evaluation (nutrient loading and chloride concentrations).

7. Viewsheds- An examination of the impacts on viewsheds will be assessed to determine if a golf course could impact this vital part of Block Island's beauty and charm.

8. Impacts to groundwater from pesticides and fertilizers will be assessed. Recent studies will be cited that claim damage can be minimal if proper management is practiced. Additionally, grasses that will grow under more droughty conditions with less fertilizer and pesticides will be mentioned.

\section{FINANCIAL ASSESSMENT}

This is a very important element in the golf feasibility study. The costs involved in developing such a project must be weighed carefully against the market of a region to determine if a golf course could be supported by the region. The local and regional economy can have a great impact on success in golf development, and thus all decisions regarding development must be soundly based on a good economic assessment of the region. 
Since a large investment in both time and money is required in the development of a golf course, it is important to determine the cost involved in developing a golf course. This section will examine projected expenses for construction of the course, projected expenses in the course operation, as well as projected revenues and other information that will help to determine if the course can be a profitable venture.

This section will also include financing options for the development of the golf course.

Important elements that will also be examined in the area of economic assessment include:

1. Another course operating in the area that would be considered similar to Block Island will be examined to determine if it is operating profitably. Such an example could help determine if a golf course could succeed on Block Island.

2. The issue of transportation on Block Island will need to be examined since many potential golfers would need to resort to public transportation to get to the golf course. Taxi's and other possible forms of transportation (shuttle busses) will be assessed.

3. Employment scenarios for the golf course will be given to determine how many jobs the course would contribute to the Island's economy.

4. A golf course has the potential of drawing additional tourist to the Island. This section will examine how Block Island could deal with this increase and mitigate most negative impacts. 


\section{REFERENCES FOR CHAPTER ONE}

National Golf Foundation. Guidelines for Planning and Developing A Public Golf Course. Jupiter, Florida: National Golf Foundation, 1989. Pg. 2-3

Town of New Shoreham. Comprehensive Plan Citizen Participation Workshop. November, 1990. 


\section{CHAPTER TWO - PROFILE OF ISLAND AND SITE DESIGNATIONS}




\section{Introduction}

The purpose of this chapter is to familiarize the reader with the general, overall characteristics of Block Island. This section will also designate the proposed golf sites so that the reader becomes familiar with the locations of these sites at the beginning of the study; before site parameters are discussed in detail in the later chapters of this study. Other areas that will be examined in this chapter include: geological history, history and social culture of the Island, Block Island's original golf course, site descriptions (site descriptions will include, acquisition possibilities, total acreage, current zoning and possible regulatory constraints), and finally the concept of zoning and how it relates to golf development.

\subsection{Geological History of Block Island}

Block Island was formed as a result of the Great Ice Age which occurred roughly 12,000 years ago (Woodworth, 1934). The immense glaciers scraped topsoil from the earth as they slowly advanced, carrying the accumulated deposits along with them. The glacial till scraped up by the advancing glacier consisted mostly of rock fragments and boulders. The advancing glacier pulverized this material to form coarse sands, silts, and clays mixed with small stones and other rock fragments. This glacier eventually covered the whole of New England.

As the Earths climate warmed, and glaciers began their retreat, they left behind the fine glacial material they had carried along with them as they advanced. This terminal moraine, as it is geologically termed, formed the Islands now known as Long 
Island, Nantucket, Martha's Vineyard, and Block Island. This glacial material is deep, and highly fertile thus making the Islands soils extremely well suited to agricultural uses. Long Island and Block Island were well known for their early agricultural history. These soils are also very porous and well drained and hence, nutrients and other chemicals have the potential to move very rapidly through the soil horizon. On Long Island, where potatoes have been grown extensively during this century, the pesticide Temic was used extensively. Tests on groundwater in the 1960's showed alarming levels of Temic present in the water. As a result stringent standards have been set for pesticide use on the Island. This example is quite convincing in showing how mobile these elements can be in these glacial terminal moraine soils.

Block Island's glacial deposits are extremely deep with no bedrock present at easily measurable depths on the Island at all. Glaciation then, has left the Island a suitable place geologically for the development of turfgrass culture, more specifically golf course development. A complete analysis of soils present on the potential golf course sites on the Island will be examined in the environmental section of this study.

\subsection{History and Social Culture of The Island}

Block Island was first sighted by the famous navigator Verrazano in 1524 . Verrazano noted that the Island was inhabited as evidenced by the fires seen burning along the shoreline. The Island had been continually inhabited by the Mannesee Indians, a branch of the powerful Narragansetts since before recorded history. Recent archeological evidence has shown that an advanced colony of Indians thrived on the 
Island year round centuries before the Island was discovered. Verrazano made no attempt to land, and it was not until 1624 that the Dutch trader Adrian Block became the first white man to land on the island. Block found Luisa, the name given the Island by Verrazano, to be unfit and quickly changed the name to Block Island in his own honor.

In 1637 the Island was annexed to the Colony of Massachusetts. The first settlers were a group of people who came from Taunton, Massachusetts. They landed at a place now known as Cow Cove on the Northern tip of the Island. A monument, known as settlers rock, was placed on the spot where these settlers landed in 1910 by the residents of the Island. The monument contains the names of these intrepid settlers.

In 1664, the Island came under Rhode Island jurisdiction and soon after, in 1672, the Rhode Island General Assembly approved the request of the inhabitants to name the Island New Shoreham.

During the early days of Block Island's history, farming played an important part in the livelihood of the settlers. They cleared the dense forests that grew previous to their arrival and replaced them with the patchwork pattern of planted fields and stone walls. Block Island's landscape today is still dominated by this patchwork of open fields and stone walls, although farming is now nearly nonexistent on the Island.

By the late 19th Century, Block Island was gaining a reputation as a summer resort. The quiet atmosphere and beautiful beaches ringing the Island were becoming a popular attraction for mainland dwellers who came to relax and recuperate. Many 
hotels and inns began to spring up on the Island as a result of this growing popularity and by the late 19th/ early 20th Century, a thriving tourist industry existed on the Island.

As a result of a Federal Grant, Block Island was given a port of call with the construction of Old Harbor on the Eastern side of the Island in 1878. This harbor was constructed to create a docking facility for arriving tourist boats as well as providing a harbor for the growing fishing industry. It was soon evident that this small harbor was inadequate to handle the growing marine traffic. In addition, the harbor was vulnerable to storms and hurricanes, offering little protection to vessels. As a result of this a channel was dredged through to the Great Salt Pond on the Western side of the Island in 1900 . This harbor was an excellent port, offering protection to vessels during storms as well as providing docking areas for fishing and pleasure craft. Today, the Great Salt Pond is a destination port for a variety of pleasure boats. During the summer months the harbor may hold as many as 1500 boats during busy holiday weekends (Littlefield, Block Island Harbormaster, September, 1990).

As time passed the fishing industry, unable to compete successfully with mainland ports, slowly dwindled; to the point where there is almost no commercial fishing on the Island at all today.

Today's residents of Block Island rely heavily on tourism for their livelihood. A golf course could potentially provide additional tourist dollars to the economy of Block Island during the summer months as well as providing new tourist dollars 
during the much slower shoulder season months of fall and spring.

\subsubsection{Block Island's Original Golf Course}

At one time a small nine hole golf course existed on Block Island. The course was known as the Vaill Hotel and Country Club and during the first half of the 20th century, it was a popular destination for Island visitors. It was located on the south shore of the Island with commanding views of the Atlantic Ocean from its perch above Mohegan Bluffs. The golf course, as well as its associated hotel were very successful through this period. After World War II however, a slow decline in tourism started to take place on the Island. Play on the golf course slowly dropped through the 1950 's and 1960 's.

By the early 1960 's, a tourist recession was impacting the entire Island. Many hotels and inns were forced to close down due to lack of bookings. Because of lack of play, Vaill golf course was no longer profitable under its current use; the land was more valuable for residential development. As a result, by the mid 1960's, land had been subdivided and sold for the development of homesites. Today little evidence remains of the old golf course; a number of homes are currently on the site where the course was once located, but it is obvious from examining the area that it must have been a very scenic site to golf upon. Vaill golf course was simply a victim of a floundering tourist economy that did not recover until the 1970 's. The final result of Vaill's closing is worth noting as well. Once replaced with homes, the site was forever lost as an area for open space. 
Block Island today is firmly established as a tourist destination and it is unlikely that the Island will lose its tourist economy anytime in the foreseeable future. With a growing healthy tourist economy, golf should become a highly sought after pastime for both tourists and residents on the Island. A golf course could help preserve open space lands from the growing pressures of residential development on the Island. Both sites in this study are zoned residential and it is entirely possible that a large portion of these lands could be lost to residential development. Preservation of open space would be accomplished through the development of a golf course, which is something that must be seriously considered when assessing the feasibility of the golf concept.

\subsection{Site Descriptions and Delineations}

In 1990, the Block Island Golf Course Study Committee (BIGCSC) was formed in order to determine if golf development could be feasible for Block Island. Headed by Mark Emmanuelle, the Committee developed a public opinion survey in order to determine if the community was receptive to the development of a golf course. They also worked to find feasible sites on the Island that had enough acreage to build a potential golf course, as well as other issues that were pertinent to golf development. If public opinion was favorable, the Committee would continue to develop a plan of action for the development of a golf course. At the time of preparation of this feasibility study, two sites were designated by the BIGCSC as being possibly favorable for golf course development (See Figure 1). 
One reason these

sites are being considered is because both areas already contain portions of land that may be considered available for golf course development. These available lands are either owned by the Town or by groups such as the Conservation Fund or the Block Island Land Trust. These groups have shown an interest in possibly providing their lands or purchasing new lands for golf development. Although only small

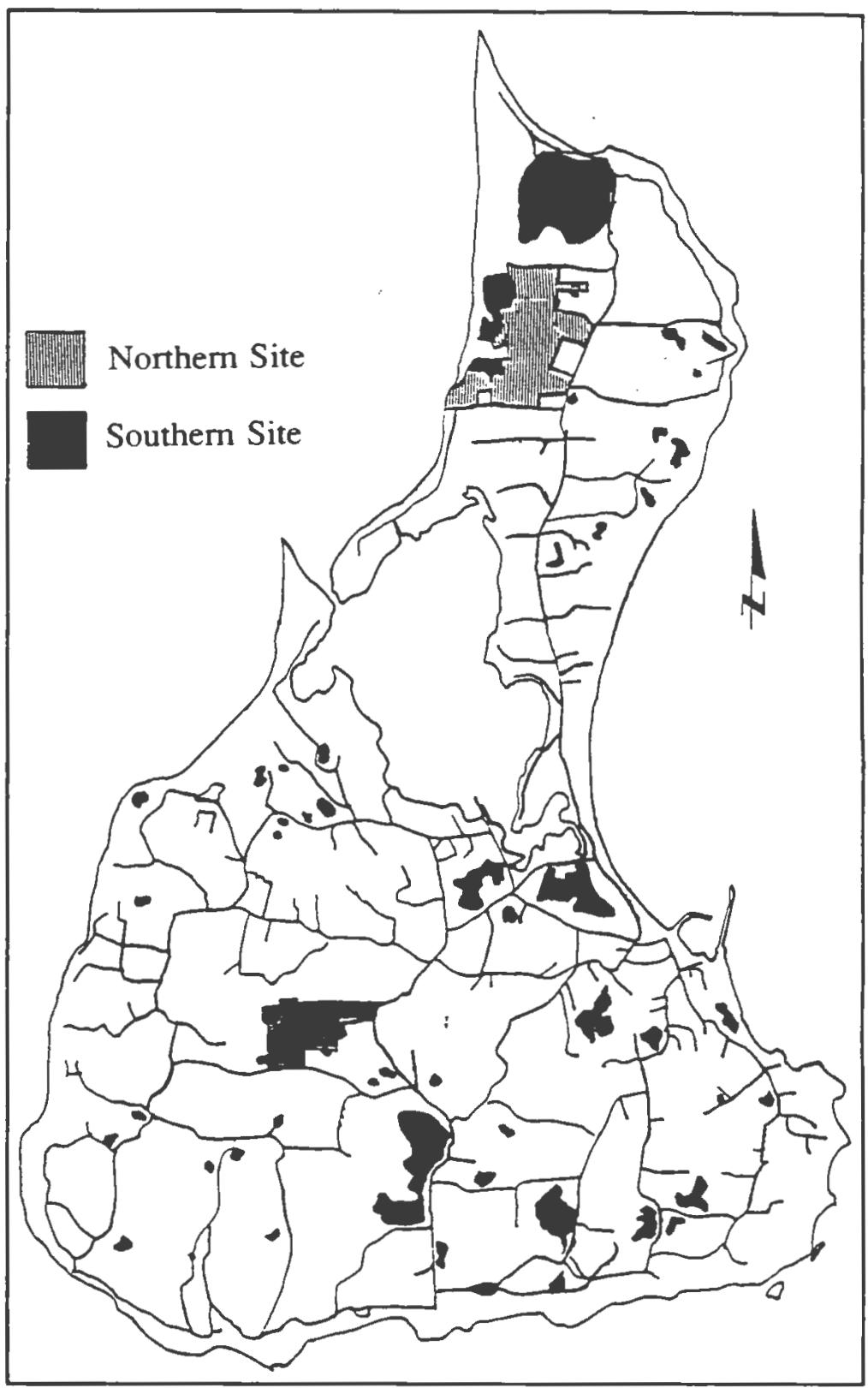

Figure 1 Location of proposed Northern and Southern golf sites.

parcels of land are

considered highly feasible for golf development at this time, other lands surrounding these properties may show the possibility of being acquired by non profit groups like the Conservation Fund and/or the Land Trust. 
This study will outline the various acquisition alternatives that potentially exist early in this process. It must be stated however that as of the printing of this document, some of these lands are under private ownership and none of have been promised for golf development. These descriptions and designations are for planning purposes only, and are only being provided so that the reader can become familiar with the various acquisition possibilities under consideration at this early stage of the development process. The feasibility of a golf course is highly contingent on the willingness of the private property owner to reach some type of agreement in the land acquisition process in order to make these golf sites feasible for golf development. Each area will be examined individually.

\subsubsection{NORTHERN SITE}

\section{Site Description and Acquisition Possibilities}

The Northern Site is roughly bounded by Corn Neck Road to the east, west Beach Road to the south and Block Island Sound to the west. The entire designated area is zoned Residential A ( 3 acre). This site was originally considered due to the fact that town owned land can be found within the area. Lots owned by the town include lot 39 (the abandoned landfill site), and lot 38-1. Total acreage for these parcels is approximately 27 acres. There are significant wetlands within these parcels however, so the amount of usable space in this area could be significantly reduced. A large parcel of land on the Northern portion of the site, known as Breeds Farm, has had its development rights purchased in order that it be permanently kept as 
open space. A portion of this property was originally considered by the Block Island Golf Course Study Committee as possible land for acquisition. A deed restriction that forbids the use of the land for recreational purposes, however, puts a severe constraint on development of this property. Nevertheless, a portion of this area is included in this study as a potential acquisition, since it may be possible to negotiate an agreement that would allow the southern portion of the property below the right of way to be used for recreation, while continuing to preserve the northern portion of the lot under its current restrictions. The lot number for the Breeds Farm Site is 30 ; the potential acreage is approximately 12 acres, assuming all lands to the south of the right of way were granted for recreational use. Other lands within the study area are privately owned. Smaller subdivided areas include lots $41,42-1,42-2,42-3$, $42-4,42-5,42-6,42-7,38-2,38-3,38-4,38-5,38-6,38-7,38-8,38-938-10,38-11$ and $38-$ 12. Total acreage for these lots combined is approximately 16 acres. Parcel $38-2$, roughly a five acre parcel, is currently on the market with an asking price of approximately $\$ 550,000$, This gives a general idea of the cost of acquiring raw acreage on these sites. Other privately owned lots include lot 33 and 34 with a listed acreage of 29.6 acres and lot 35 with a listed acreage of 40 acres. Lot 35 is partially developed with a residential property on the eastern border of the lot, and it is very likely that only a portion of this property if any at all would be made available for development.

Private conservation groups such as the Conservation Fund have expressed a desire to negotiate with private owners of these lands in order to acquire all or 
portions of their land for golf development. The development of this site then, is highly contingent on the private owners willingness to embrace the golf concept and sell or provide easements on their lands for such use. If the purchase of adequate amounts of privately owned land cannot be accomplished, severe constraints would exist in terms of development of this site. Owners of lots unwilling or unable to sell, may agree to easements running through their property in order to provide access to lands that can be acquired. Lot 35 may require this easement option since acquisition of the smaller subdivided lots to the south and lot 34 to the North would be useless for golf development unless some type of linkage could be devised between the two areas. Acquisition of at least a portion of lot 35 would be highly useful to the development of a golf course on this site.

As stated earlier, there are a variety of acquisition possibilities within this Northern study area; more complex than the Southern Site. Therefore, golf feasibility in this area is highly contingent on acquiring or obtaining easements on a substantial portion of the lands shown within the designated site area shown in Figure 2. Only time will determine if these lands can be successfully acquired.

\section{Total Acreage of the Site}

Assuming all lots or portions of lots shown within the site area in Figure 2 are acquired, a maximum of 115 acres is conceivable. This figure is a best case scenario and it would be unlikely that all this land could be acquired for golf development. A figure of 80 to 90 acres would be a more realistic acquisition goal for this site. In 
addition, some of the lands would probably be lost to coastal protection, since the Coastal Resource Management Council (CRMC) would undoubtedly assign a 200 foot buffer around the important coastal ponds known as Wash and Middle Pond, so due to this, potential usable lands could be reduced even further. (See attached foldout map (Figure 2) delineating the proposed Northern site)

\section{Possible Regulatory Constraints}

This area has two brackish ponds and associated wetlands that are very near the primary dunes stretching north to south on the western portion of the parcel. These ponds will undoubtedly be considered a coastal wetland feature by the Coastal Resource Management Council (CRMC), and appropriate 200 foot buffers will be placed around these important coastal features. The ponds, in fact are considered conservation areas as deliniated in the State of Rhode Island's Coastal Resources Management Program, and as a result, protection measures would be expected to be stringent. Consequently, 20 to 25 acres of this area will be lost as a result of these protective buffers. The reduction means that only about 95 acres could be considered for golf development. This is still ample room for a nine hole course if no other constraints are encountered. The small kettle hole ponds on the site should carry no constraints, due to the fact that they have no inlets or outlets. At most a 50 foot buffer would be placed around them. 


\subsubsection{SOUTHERN SITE}

\section{Site Description and Acquisition Possibilities}

The Southern site is roughly bounded by Old Mill Road to the south and Center Road and Block Island Airport to the east. The study area is currently zoned Residential A ( 3 acre). Several important parcels are owned by either the town of New Shoreham or the Block Island Land Trust. Lot one, known as Nathan Mott Park, is owned by the Town of New Shoreham. It is a 29 acre parcel that shows high feasibility for golf development since it is currently earmarked for future recreational use. Other lots owned by the Block Island Land Trust show promise for development. These include lots $17-1,17-2,18,74-2,74-3,74-5,74-6,74-7,74-8,74-15$, and 74-16. Total acreage for these lots combined is 25 acres. Part of lot 2 is owned by the State of Rhode Island. The lot has runway lights for the state airport on part of the property, but it is quite possible that the remaining portion of this property could be acquired for golf use. Winnapaug golf course uses airport clear space for golf use. The state would most likely be receptive to the idea of utilizing this area for constructive recreational use. The total approximate acreage for this area would likely be approximately 10 acres. The remaining land is under private ownership and acquisition of this land would require the approval of the owner for development. These parcels include 74-16 and 74-10; total area, 5.3 acres. 


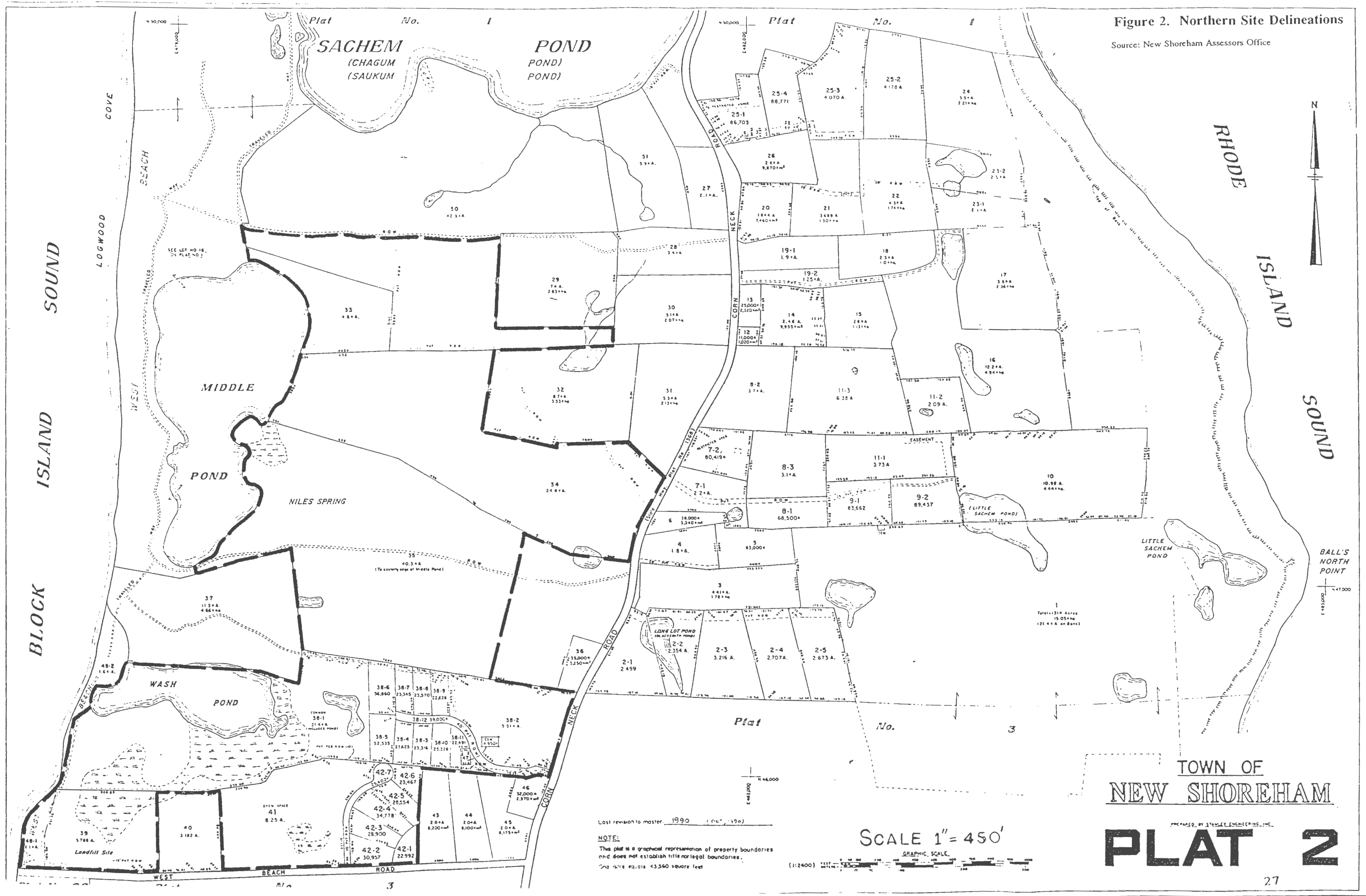




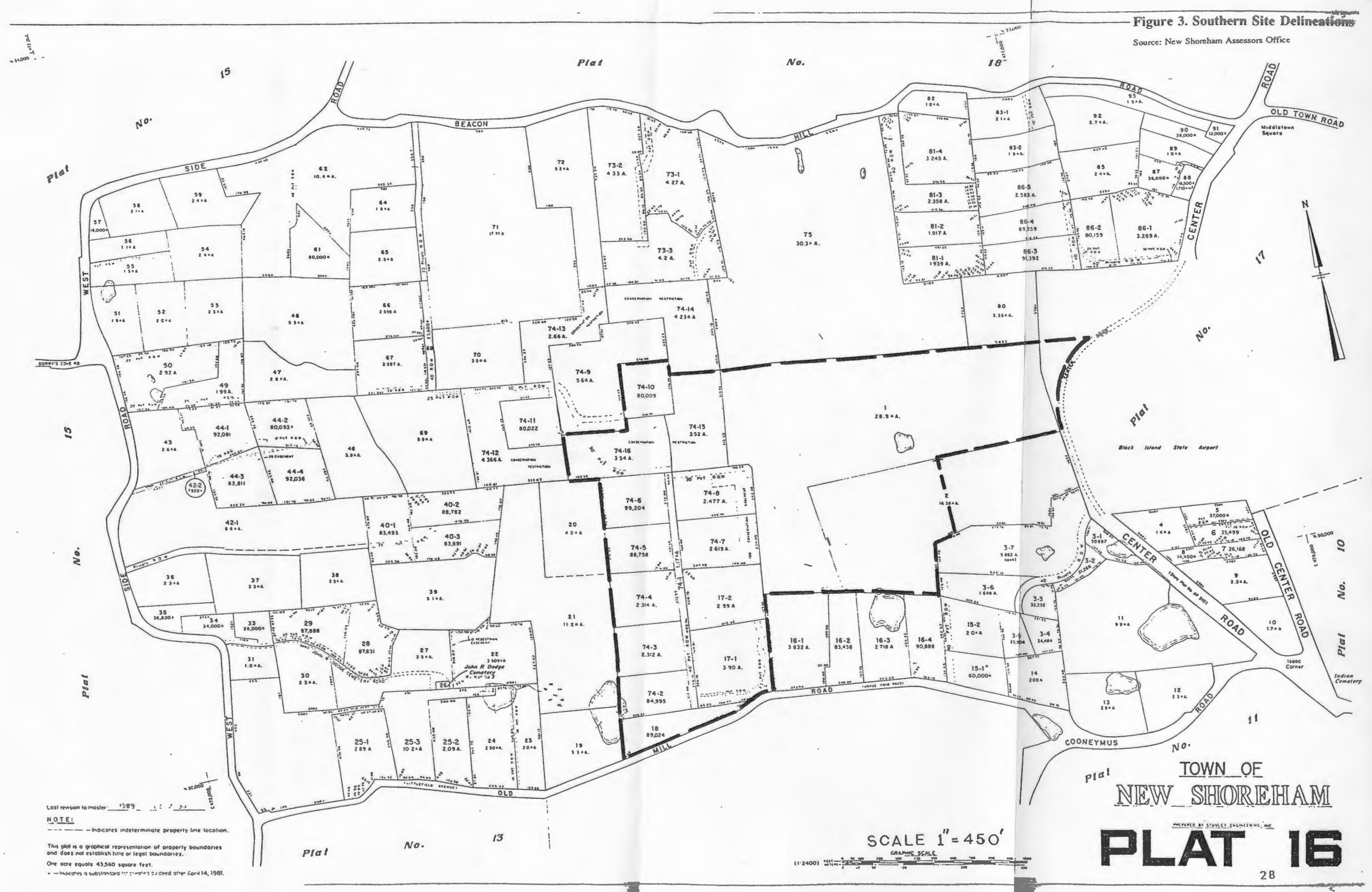




\section{Total Acreage of the Site}

Total acreage, assuming all lands can be acquired, is approximately 70 acres. This would probably be the minimum amount of land required to build a nine hole golf course, assuming that all portions of the land were developable, which is unlikely. Additionally, part of these lands are under conservation restriction, which bans them from being developed in any manner. This restriction includes an important stand of Japanese Black Pine known as the Enchanted Forest. If parcels of land to the west and north of the current delineations could be acquired, it would raise the total acreage of this area, thus improving the possibility for golf development here. Based on acreage then, severe constraints exist on this site, unless extra land can be acquired. (See attached foldout Map (Figure 3) delineating the proposed southern site).

\section{Possible Regulatory Constraints}

There are a few small ponds associated with these sites, they are however, kettle type ponds with no stream inlets or outlets, and consequently regulatory constraints would most likely be minimal. 


\subsection{Zoning for Golf}

Zoning is not always considered in the development of a golf course, but it should nevertheless play an important role in the development process. Two important factors must be dealt with in zoning for golf. They are as follows:

1. Buffer zones

2. Parking Requirements

The current zoning regulations have only one zoning requirement written related to golf course development; that there must be a $100^{\prime}$ buffer zone between the edge of the golf course property and abutting properties. This requirement would be an extreme constraint to development, since it would tie up an inordinate amount of land to non use. Severe reductions in usable acreage would be anticipated.

It would be recommended that this regulation be modified so as to become less restrictive to the development of the golf course, a revision to allow for maximum use of land for golf development while providing safety and privacy to neighboring property owners could probably be devised so as to be equitable to all parties involved. A smaller buffer or perhaps conservation easements could be utilized to soften the restrictions of this regulation.

Zoning requirements for parking are usually included in communities with extensive golf development. Generally, parking requirements are in the area of four spaces per green. Usually parking is the only stipulation mentioned in zoning. Since automobile traffic is limited on the Island and since most players would most likely use taxi's to get to the golf course (see Chapter Four) zoning regulations on Block 
Island would probably not have to be as stringent as areas that are easily accessible to automobile traffic.

\subsection{Findings}

This chapter has provided the basic framework for the development of this feasibility study. The findings include:

1. The geological history of the Island shows that it is well suited for the development of a golf course.

2. The original Vaill golf course failed as a result of the failing tourist economy in the 1960 's as well as increased pressure for residential development of the Island. The successful future of a proposed golf course, then, is contingent on the health of Block Island's tourist industry. Preservation of open space through golf course development can also reduce the possibility of these lands being sold off to residential development.

3. Site deliniations and descriptions of ownership, acquisition possibilities, current zoning and possible regulatory constraints give the reader the information required

to examine and assess the remaining chapters of this study with full knowledge of the sites physical parameters.

4. Zoning is important to the development of a course. Issues such as parking requirements and buffer zones must be resolved within the zoning ordinance before the development of a golf course. 


\section{REFERENCES FOR CHAPTER TWO}

New Shoreham Harbormaster. Littlefield, Christopher: Great Salt Pond Site Tour, September 12, 1990.

Woodworth J.B. and Wigglesworth Edward, Geology of Block Island: 1934: Harvard College Mus. Comp. Zoology Mem, v. 52. 


\section{CHAPTER THREE - GOLF COURSE NEEDS ASSESSMENT}




\section{Introduction}

This chapter will analyze a variety of parameters that will determine if there is a need for additional golf destinations in Rhode Island, as well as Block Island. Areas that will be examined in developing this needs assessment will include:

demographic analysis of both Rhode Island and Block Island, golf demand and supply in Rhode Island and Block Island (using National Golf Foundation and Tyrell and Manheims statistics), assessment of public opinion regarding golf development on Block Island, recreational needs of the residents of New Shoreham, and finally, the need to acquire open space for preservation on Block Island.

\subsection{Demographics}

Of paramount importance when developing a feasibility study, demographics will help determine if there are enough people coming to the Island to support a golf course. Three important groups must be analyzed when determining how many people are on the Island at the various times of the year. They are:

1. Year Round residents

2. Seasonal Residents

3. Tourist Visitors

According to the preliminary 1990 US Census figures there are 765 people currently residing year round on the Island. This number is relatively uncontested. Block Island is ranked 39th out of the 39 City's and Town's in Rhode Island.

Assessment of the numbers of people on the Island on any given day during the 
summer season are more difficult to determine since several estimates have been generated by various groups on the Island. The numbers vary greatly according to whose survey you examine. Probably the most impartial and unbiased assessment of tourist season population is found in the study by Tyrell and Manheim titled, "The Social and Economic Impacts of Tourism on Block Island" (Tyrell, Manheim, 1986). The information provided in this study is widely regarded as the best source of population data available for the Island, and as a result, this study will base its assumptions on the information provided in Tyrell and Manheim's study.

The study breaks the non year round population into the following categories:

1. Seasonal Residents- According to the survey, seasonal residents swell the year round population by an estimated $\underline{2,500}$ people.

2. Hotel Motel and Inn Guests- The 35 hotels, guest houses, cottages and apartment facilities can accommodate approximately $\underline{1,466}$ visitors a night during the summer season.

3. Boaters- Based on interviews it was estimated that the harbors may be host to as many as 400 boats at any given time. Based on 3.7 persons per boat, there are an average estimated $\underline{1,480}$ boating visitors daily to Block Island.

4. Day Trippers- This group arrives for one day visits to the Island via ferry service from a variety of locations, primarily Point Judith and New London. Based on the study it was estimated that as many as 1.737 same day return visitors arrive on the Island daily. 
The study designated an 84 day season for the above figures. Some seasons may be marginally longer or shorter than this figure but in this assessment the 84 day season will be used. Based on these parameters, Table 1 enumerates total population counts for the various groups that make up the summer season tourist population.

The results show that on any given day during the tourist season, an estimated $\underline{4,683}$ tourists could potentially be on the Island. When this is added to the $\underline{765}$ year round residents and the $\underline{2.500}$ seasonal residents, there could potentially be as many as $\underline{7.948}$ persons on the Island in any given day.

TABLE 1 Estimated Number of Tourists by Type and Total Tourist Days Type of Tourist Number of Tourists Total Number of Days

1. Overnight Visitors

a. In hotels, motels and Inns

1.050 (X 84)

88,200

b. In cottages 416 34,944

2. Overnight visitors by Boat

1,480 124,320

3. Day Trippers* 1.737 145,908 Total 4683 per day 393,372 per season

* Includes day trippers from Providence, New London, Newport and Point Judith. Source: Tyrell, Manheim, The Social and Economic Impacts of Tourism on Block Island; 1986.

From these results it is evident that there are substantial numbers visiting the Island during the summer months. Weekends during the shoulder months provide a 
fair amount of tourist income according to the Chamber of Commerce and the various hotel and inn owners who were interviewed. Data quantifying the number of visitors during these periods are not available, however. There is no doubt, however, that this group could be considered as potential players on a golf course during the shoulder months.

\subsection{Golf Demand and Supply in Rhode Island}

Determining demand and supply for golf on Block Island is somewhat different than the techniques that would be applied for supply and demand models on the mainland. Block Island's isolation from mainland golf courses mean that a demand and supply model must be modified to account for this isolation.

In many ways Block Island could easily be considered a virgin market, since there are currently no golf courses at all on the Island. A study of golf market conditions in Rhode Island as well as an examination of golf participation rates of the various states that the majority of tourists on Block Island come from is worth examining. This will tend to reinforce the National Golf Foundation's opinion that golf is a growing sport that requires more golf courses to keep pace with the reported growing participation rates.

\subsubsection{The Growth of Golf}

According to the National Golf Foundation (NGF) there is a golf boom taking place within the United States. Studies indicate that there are presently 23.4 million 
golfers with an expected annual growth rate of 2 to 3 percent (National Golf Foundation, 1989). At this rate of growth, there should be nearly 30 million golfers by the year 2000 . NGF studies further indicate that the core of golfers (those who play more than three rounds annually) total approximately 13 million. By these standards the NGF estimates that nearly 470 courses will be needed each year for the next ten years in order to meet the growing demand being placed on the golf market.

In examining the Rhode Island market, we find that there are an estimated 77,774 golfers with a participation rate of $8.4 \%$ (National Golf Foundation, 1990). Other statistics that will be useful in generating a demand model include:

1. Average Rounds per year per golfer- 24

2. Older Golfers have the highest golf participation rate.

3. Rhode Island has the second highest percentage of seniors in the country. Seniors show the highest golf participation rate of all age groups assessed.

\subsubsection{Rhode Island Golf Demand Analysis}

By using the figures provided above it is possible to determine the number of rounds per year played by the residents of Rhode Island.

* Rhode Island Golf Demand in 1989

- Rhode Island Golf Population.............. 77,774

- Number of average rounds per golfer........... 24

Total rounds per year for Rhode Island.. 1,865,376 
Surveys with several golf course managers in Southern Rhode Island stated that average waits on their courses on weekends usually were at least $21 / 2$ to 3 hours during the 1990 season. Many reported number of rounds on their individual courses approaching or exceeding 40,000 rounds per year (see Appendix B for a list of courses contacted). It is obvious from these comments that Southern Rhode Island's golf courses are heavily used.

\section{Tourist Impacts}

Rhode Island is rapidly becoming a more popular tourist area. Places like Block Island, Newport and the south shore of Rhode Island are becoming popular alternatives to overcrowded resort areas like Cape Cod. Coupled with the fact that many vacationers prefer to remain closer to home during times of weaker market, it is easy to understand why Rhode Island's tourist industry is growing. According to a study conducted by the Advantage Research Corporation and coupled with statistics from the Rhode Island Tourism Information Center it is estimated that nearly 22 million vacationing tourists came to Rhode Island in 1988 (Veri, 1988). The great majority of these tourists vacationed in Southern Rhode Island. 
Tourists are also a potential golf group and must be included in the demand model. The National Golf Foundation estimated the national average golf participation rate to be approximately 10.4 percent. Using this statistic we can deduce the following:

\section{Tourist Potential Demand}

* Number of vacationing tourists......... 22 million

* Golf participation rate.................. 10.4\%

* Vacationing tourist potential demand.... 2.28 million

It is assumed that only a fraction of these 2.28 million tourists will golf during their stay. Therefore it will be assumed that only $25 \%$ of the potential 2.28 million will golf once during their visit.

Modified tourist golf demand: 2.28 million X $25 \%=\mathbf{5 7 0 , 0 0 0}$

Combining Rhode Island golf demand with tourist demand yields a total annual golf demand of: $\mathbf{2 , 4 2 6 , 3 7 6 ~ R o u n d s ~}$ 


\subsubsection{Golf Supply In Rhode Island}

According to National Golf Foundation statistics, there are 48 golf courses in Rhode Island. They are broken down into the following:
1. Daily Fee -24
2. Municipal - 3
3. Private $-\underline{-21}$
Total 48 Golf Courses
Total number of holes - 594

Source: National Golf Foundation, 1989

The following will be assumed in determining annual golf capacity:

Average number of rounds per course $-230^{*}$

Average length of season $\quad-210$ days

- Based on an average of one foursome starting every eight minutes.

Season Capacity $=48$ courses $X 230$ rounds $X 210$ days $=\mathbf{2 , 3 1 8 , 4 0 0}$

This denotes a total supply of $\mathbf{2 , 3 1 8 , 4 0 0}$ rounds per year.

\subsubsection{Supply vs. Demand}

The model shows the demand exceeds the supply as enumerated below:

Demand.................. 2,426,376 Rounds

Supply................. 2,318,400 Rounds

Shortfall.............. 107,976 Rounds

This shortfall would denote the requirement for approximately two new eighteen 
hole courses in the region to match current golf demand. This model assumes that there is an equal amount of play for each day during the season. This is actually not the case. The often heard statement of waiting $21 / 2$ to 3 hours for a tee time generally refers to conditions during weekend play. Most golf course managers surveyed stated that there was very little wait for golfers during most weekdays. It must be remembered then, that the vast majority of golf demand takes place during weekends and holidays.' This makes sense, since this is the only time when most golfers are able to play. It nevertheless represents a flaw in the model that is difficult to correct. Additional golf courses could reduce the great weekend demand we see and make a round of golf much more enjoyable for the player.

The demand and supply analysis shows that there is a regional demand for golf, although the need may not be as great as the National Golf Foundation statistics would lead us to believe.

Several recent articles have been critical of National Golf Foundation statistics, stating that the extrapolation techniques used by the organization can create misleading numbers (Forbes Magazine, December, 1990). One major criticism the articles have with the NGF is its assumption that a golfer is "anyone over the age of five who plays golf once annually". This does seem rather liberal and possibly unrealistic in developing a golf participant cross section. Another article suggests that golf growth in Rhode Island seems to be slowing, and more caution is required when considering developing a new golf course (Providence Business News, January, 1991).

An older golfer of perhaps 10 to 12 years of age who plays more frequently than 
once a year would produce better numbers. The Forbes article states that despite the positive projections made by the NGF, 6 courses in New England filed for Chapter 11 last year.

This analysis used NGF statistics because they are still considered to be one of the best sources available for obtaining golf related statistics and although there are some groups challenging the statistics being generated, few alternatives are available at this time.

Any decision to build a golf course involves some degree of risk, and the articles sited are only provided to show there are alternate opinions to the tremendous golf growth projections which the National Golf Foundation is currently predicting.

In as many instances as possible, other sources of data were explored in trying to determine demand and supply in order to maintain conservative estimates for this section of the study.

\subsubsection{Block Island Golf Demand and Supply}

The previous section was provided to show that there is regionally a demand for golf. Block Island, as stated earlier, must be treated somewhat differently due to its isolated condition. Tyrell and Manheim's demographics studies provide a good estimate of resident and tourist populations on the Island. Using participation rates for the various states where the most tourists visiting the Island come from it is possible to determine the potential demand for golf on Block Island for the busiest months on the Island; June July and August. 
The states where most of the tourists come from, include:

STATE

Rhode Island

New York

Connecticut

Massachusetts

New Jersey

Pennsylvania

\section{GOLF PARTICIPATION RATE}
8.4 Percent
8.9 Percent
10.8 Percent
11.5 Percent
9.1 Percent
8.4 Percent

Source: Block Island Chamber of Commerce.

The Block Island Chamber of Commerce reports that the majority of tourists arriving on the Island come primarily from these six states. Using NGF statistics, the average participation rate for these states combined is $9.5 \%$; slightly below the national average.

Using the previous figure of 393,372 seasonal visitors (see Table 1), we can determine demand.

$$
\text { Tourist Demand }=393,372 \times 9.5 \%=\mathbf{3 7 , 3 7 0}
$$

If we assume that $25 \%$ of these people play golf once while visiting:

$$
37,390 \times 25 \%=9,347 \text { Golf Rounds }
$$

Seasonal residents number 2500 :

$$
\begin{aligned}
& 2500 \times 9.5 \%=237 \text { players } \\
& 237 \times 8^{*}=\mathbf{1 , 8 9 6} \text { Golf Rounds }
\end{aligned}
$$

\footnotetext{
* Seasonal residents spend approximately four months on the Island. Eight rounds represents $1 / 3$ of the 24 rounds played by the average golfer.
} 
The last major group, year round residents, have the potential of playing a 210 day season or longer. This computes accordingly:

$$
\begin{aligned}
& 750 \times 8.4 \%=63 \text { players } \\
& 63 \times \quad 24=\mathbf{1 , 5 1 2} \text { Golf Rounds }
\end{aligned}
$$

The total golf rounds for all three groups combined totals: $\mathbf{1 2 , 7 5 5}$

This total accounts for all visiting tourists and seasonal residents rounds during the summer season, and the number of rounds played in the 210 day season for the year round residents. It does not account for any golf rounds that would be played during the shoulder seasons by visiting tourists. This number is difficult to quantify, since no studies have been conducted to determine the actual numbers arriving during these months.

Interviews with hotel and inn managers indicated that they were able to fill their hotels on weekends a few weeks before and after the 84 day summer season, with numbers dropping off during the early spring and late fall.

An estimation must be devised to help provide rough figures for arriving tourists during these shoulder months.

To do this, the following will be assumed: $50 \%$ of the on season tourist counts for hotel and inn occupancy will be determined for all weekends within the shoulder season. Additionally, $50 \%$ of the number of day trippers arriving during the on season will be computed for all weekends during the shoulder season. Assuming that the months of April, May, September and October are part of the shoulder season, we find there are 32 weekend days within these months. Assuming this, the following 
can be computed:

Tourists at hotels and inns- $1,466 \times 50 \%=733$

$733 \times 32=23,456$ visitors

Day Trippers- 1,737 X 50\% X $32=27,792$ visitors

Total Visitors 51,248

Assuming a 9.5\% participation rate: $51,248 \times 9.5 \%=4869$ rounds

As before, assuming $25 \%$ play golf: $\quad 4,869 \times 25 \%=1217$ Rounds

This figure can be added to the previous figure of 12,755 to give us an estimated total rounds of: 13,972 Rounds

This conservatively represents the total estimated demand that currently exists on Block Island. Considering that there is currently no golf course on Block Island, these results denote that there is an unmet demand for golf on the Island. If a golf course already existed on the Island, current demand would probably already be met. The figures would tend to suggest that the Island would only be able to support one small golf course under current demand.

Many of the previous figures will be used in the financial assessment section of this report to determine the profitability potential of a golf course using current demand figures.

\subsection{Public Opinion Surveys}

Public opinion plays an important role in determining golf feasibility. To help assess the general attitudes of the people who live and work on Block Island, a 
variety of key informant interviews were conducted to determine how different groups on the Island felt about the golf concept. In addition, an important secondary source of information came from a Block Island Golf Course Study Committee (BIGCSC) survey. This survey, which was placed in the September issues of the Block Island Times, asked the Island community to answer a variety of questions related to the development of a golf course on Block Island. The questions and results of this survey are covered in their entirety in Appendix A, but the overall results showed that residents favored the development of a golf course of some kind by a three to one margin. This is important, since it shows in these early stages, that there is an interest in the golf concept. Favorable results like this mean that the BIGCSC can continue to examine the possibilities of golf development on the Island with a reduced risk of public backlash.

As stated earlier, primary research was conducted to receive input from a variety of interest groups on the Island. These included:

1. Hotel and inn owners and managers

2. The Block Island Chamber of Commerce

3. The Block Island Taxi Commission

These groups have a vested interest in improving the tourist economy on the Island, so as expected, all who participated in the key informant interviews were highly enthusiastic at the prospects of a golf course on the Island. An analysis of the individuals who were interviewed can be seen in Appendix C. 


\subsection{Block Island's Recreational Needs}

A very important element to the social and physical well being of the residents of Block Island is recreation, especially during the slow winter months. Casual conversation with a variety of residents on the Island showed that many would like to see new forms of recreation available in which they could participate. The recent construction of a basketball gym at the school proves this point adequately. The gym receives heavy use by the residents. Basketball leagues have been established, and many feel that the games add excitement to an otherwise boring winter lifestyle on the Island.

Seasonal temperatures on the Island mean that year round golf could be a possibility, thus providing additional winter recreation for the residents. The addition of a golf course would provide new forms of recreation that could further enrich recreational opportunities for the residents of Block Island. Comments from the BIGCSC help show that many year round residents react favorably to the addition of new forms of recreation (See Appendix A). The golf course would definitely be a valuable addition to the recreational resources available to residents and tourists alike.

\subsection{Open Space Preservation}

Another added benefit that a golf course could provide for, is open space preservation. A links design by its very nature is able to coexist harmoniously with its surrounding environment. Many of Block Island's forms of wildlife would be able 
thrive on this type of course, since the overall characteristics of the links course would only alter the site minimally.

The addition of walking or nature trails would further capitalize on recreation and open space utilization for the broad population of tourists and residents alike.

Acquiring open space is an expensive proposition, so it is highly advantageous to have open space that provides a return on the investment. The development of a golf course would be an innovative way to preserve open space for future generations while at the same time relieving the tax burden on the community in the quest to further preserve open space on the Island.

\subsection{Findings}

The statistics amassed by Tyrell and Manheim's study, The National Golf Foundation (NGF), and information provided by a variety of other sources, seem to show that there is an unmet demand at present for golf on Block Island. The fact that the supply and demand analysis shows the need for more golf courses in Rhode Island, only strengthens the arguement that golf could succeed on Block Island. Block Island currently has no golf course, so it immediately becomes evident that there is an unmet demand for golf on the Island. Public opinion surveys would seem to suggest that the desire for a golf course on Block Island by the residents is high (see Appendix A). Coupled with the fact that new recreation sources are needed on the Island and with the fact that open space preservation is a high priority on Block

Island, it is reasonable to say that there is a need for golf on Block Island. A golf 
course would boost the economy of Block Island as well as provide recreational opportunity and open space preservation. 


\section{REFERENCES FOR CHAPTER THREE}

Block Island Chamber of Commerce; Telephone Inquiry Questionnaires, 1989 - 1990.

Rudnitsky, Howard and Koselka, Rita: Extrapolation Madness, Forbes Magazine, December 24, 1990. Pg 56-61.

National Golf Foundation; Guidelines for Planning and Developing a Public Golf Course, Jupiter Florida: National Golf Foundation, 1989.

National Golf Foundation; Mr. John Anderson, Telephone Conversation, October, 1990.

Forrest, Wayne; In a Sand Trap, Providence Business News, January, 1991. Pg 11-15.

Tyrell, Timothy and Manheim Patt; The Social and Economic Impacts of Tourism on Block Island: A Case Study, Resource Economics, The University of Rhode Island, NOAA Sea Grant, Marine Technical Report 89. March, 1986.

Veri, Albert and Associates; Feasibility Report: Ninigret Park Municipal Golf Course, April 24, 1990. Pg. 14. 
CHAPTER 4.0 - ENVIRONMENTAL ASSESSMENT 


\section{Introduction}

This chapter will begin by examining the type of course that would be most suitable to the landscape and character of Block Island. The "links design" will be compared to the more traditional American courses that most are more familiar with.

This chapter will also examine all environmental elements that could cause constraints to the development of the golf course. Each site will be individually evaluated according to a number of environmental parameters, including: climatological history, topography, soils, wildlife, vegetation, ground and surface water resources, and impacts to surface and groundwater from fertilizers and pesticides.

Additionally, this chapter will outline fertilizer requirements for the golf course as well as possible turf cultivars that can be successfully used on the "links" golf course. Possible impacts to viewsheds will also be assessed.

\subsection{Golf Course Design: The "Links Course"}

Golf is the only major sport without a standardized playing field. Golf course designers really have a fairly free hand in terms of designing a course. The architect, however, must design a course that co-exists with the landscape; a course that is challenging, but at the same time is in total harmony with its surrounding environment. A wide variety of golf course designs exist that tend to enhance their surrounding environment. Much depends on the area where the course is being proposed. The perfectly manicured layout of the Augusta National Club is a masterpiece in design, that fits into its environment most effectively. This, as well as 
other highly manicured and flawlessly maintained courses are relatively expensive to maintain from an agricultural standpoint. They need intensive management in terms of mowing and total maintenance and in addition, require copious amounts of fertilizer, pesticides, water and manpower to maintain the near perfect conditions.

It is not difficult to imagine that this course is not suitable to the landscape of Block Island. It would not fit in well with the landscape nor would it fit in with the social and cultural environment of the Island.

The rural character as well as its seaside location, with rolling dunes, beachgrass and low shrubs make the area much more eligible for a "links" style design. The land is in many respects similar to the linkslands of Scotland, generally considered to be the birthplace of golf.

Links courses are designed with the notion of retaining sand dunes, low brush and other related pre-existing vegetation that are found on much of the Island. Fine fescues form a tough, resilient grass that forms an excellent dense turf that thrives with less water, fertilizers and pesticides than the more commonly used grasses used on golf courses, namely, Bluegrasses, Bentgrasses, and Perennial Ryegrasses. This Scottish links appearance creates a more natural, environmentally harmonious course that will not detract, but add to the landscape of the Island. This design could be a valuable addition to preserved open space on the Island. The golf course could generally be considered one of the more gentle uses for land designated to be preserved as open space. And unlike many areas designated as open space this land could actually generate revenues for the town. 
Photographs of the Northern site (Figure 4) with its rolling landscape, low brushy bayberry and grass covered dunes show how aptly suited this area is to the links design,especially when it is compared with the photograph of the Saint Andrews Golf Club in Scotland (Figure 6), the most famous of links style golf courses. The Southern site is also a good candidate for the design although the inland location lacks the dunes and beachgrass of

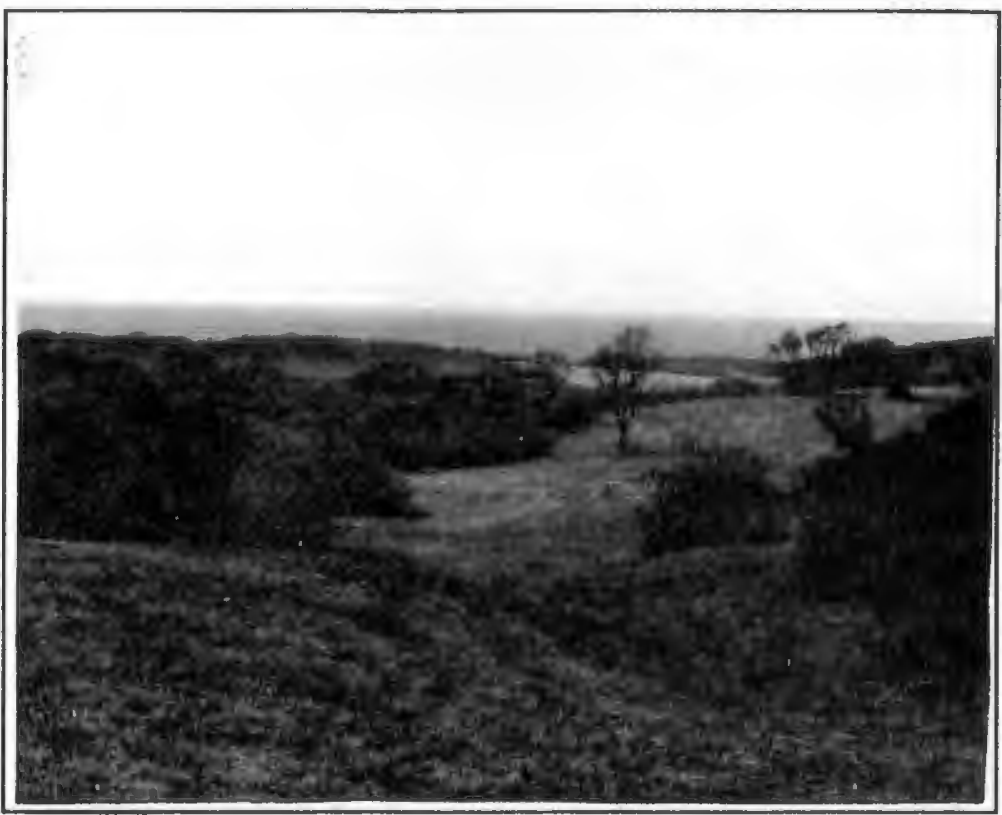

Figure 4 Northern Site, looking west.

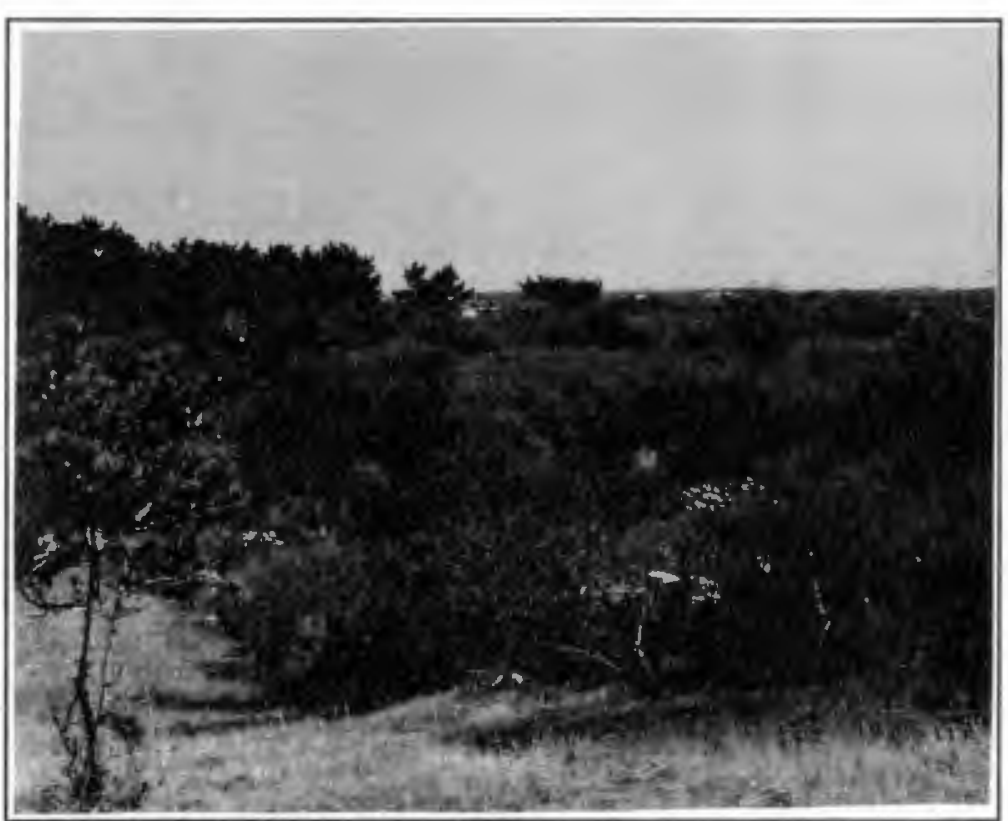

Figure 5 Southern site, looking southeast. the Northern Site

(Figure 5). The area provides only modest viewsheds compared to the Northern site and in addition, more modification would be required in the development of this 
area due to greater amounts of unwanted vegetation covering a large portion of the area. It may also be necessary to modify the topography of the site; which would make the area potentially more expensive to develop.

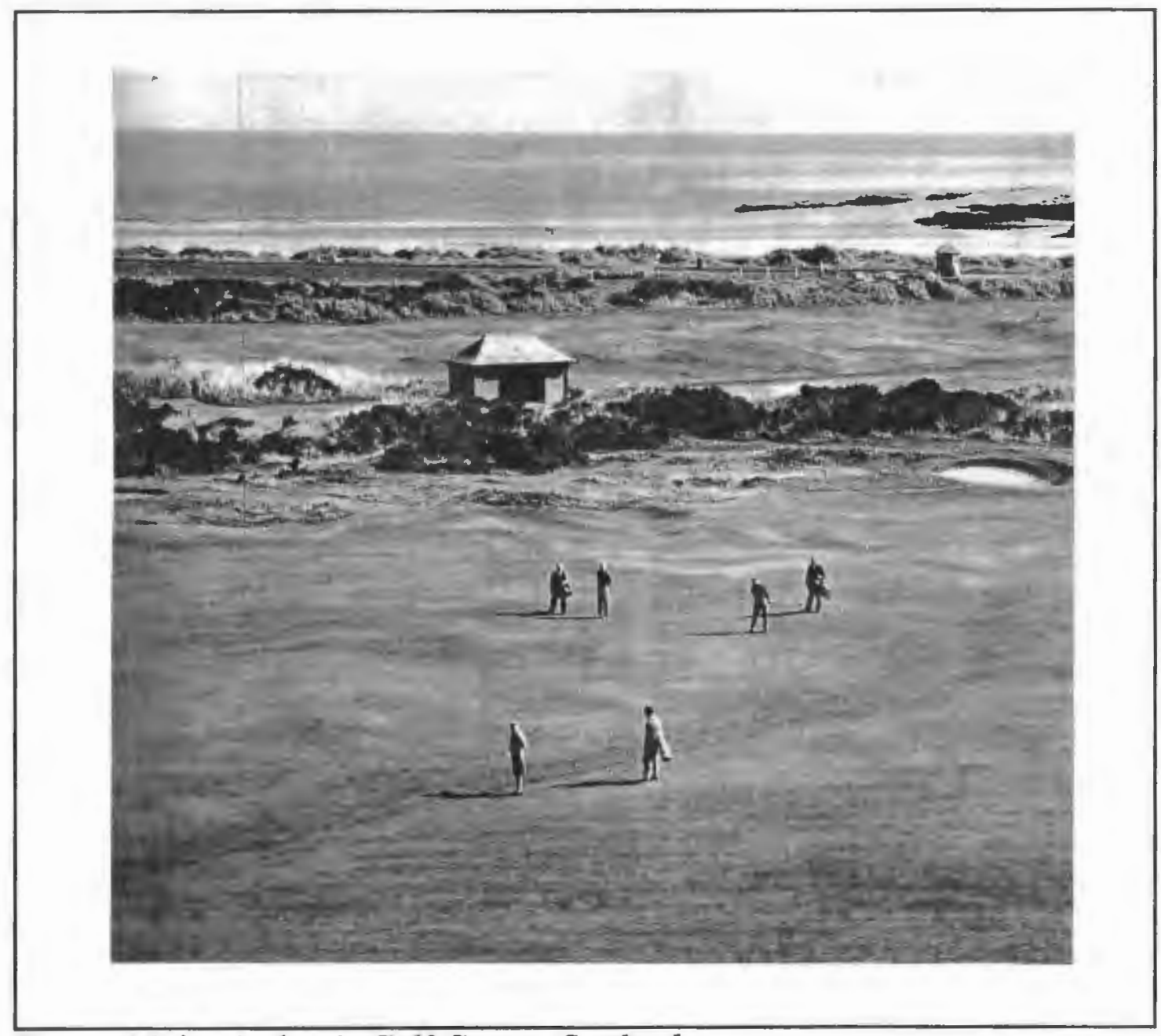

Figure 6 Saint Andrew's Golf Course, Scotland

Source: Urban Land Institute, 1974 


\subsection{Climatological History}

Climate is an important element in golf feasibility. The length of a golf season varies depending on latitude, proximity to geographic features such as large bodies of water and altitude (ie. mountainous regions). Any of these can have regional affects on climate. Block Island's proximity to the Atlantic Ocean means that it will be greatly impacted climatologically by it. Typically, springtime temperatures are lower than inland regions of the mainland due to the cooling effects of the cold ocean. Conversely, fall temperatures tend to remain higher due to the impacts from a warm ocean. For Block Island, this translates into a warm season that generally starts later in the spring than inland areas, but lasts longer than inland areas during the fall months. An examination of average monthly temperatures from 1969 to 1989 (Table 2) show this trend. Temperatures tend to remain slightly lower in early spring while they tend to remain slightly warmer during the late fall.

As a general rule, temperatures marginally above or below 45 degrees would tend to be the cutoff for golf participation. This study will assume that the majority of golfers would prefer to play above this cutoff temperature.

According to the temperatures provided in Table 2, the golf season could begin sometime in late March and extend to sometime in early December. This realistically represents an eight to nine month season. The possibility of mild weather on the Island could conceivably extend this period.

It is obvious that the summer months are fine weather for golf, and participation would be expected to be high. 
Table 2 Average Monthly Temperatures, Block Island, Rhode Island, 1969 - 1989

$\begin{array}{llllllllllllll}\text { Year } & \text { Jan } & \text { Feb } & \text { Mar } & \text { Apr } & \text { May } & \text { Jun } & \text { Jul } & \text { Aug } & \text { Sep } & \text { Oct } & \text { Nov } & \text { Dec } & \text { Annual } \\ 1969 & 30.7 & 30.6 & 34.7 & 45.7 & 54.8 & 64.9 & 69.0 & 71.4 & 64.3 & 54.6 & 45.8 & 34.4 & 50.1 \\ 1970 & 24.3 & 30.6 & 35.3 & 44.6 & 54.9 & 62.1 & 70.8 & 71.4 & 64.3 & 55.7 & 47.4 & 33.7 & 49.6 \\ 1971 & 26.8 & 31.8 & 36.3 & 42.9 & 53.3 & 63.6 & 70.8 & 70.1 & 67.4 & 59.7 & 44.1 & 38.8 & 50.6 \\ 1972 & 33.7 & 30.9 & 36.0 & 42.5 & 53.5 & 61.6 & 71.4 & 70.3 & 64.3 & 51.6 & 43.7 & 38.7 & 49.9 \\ 1973 & 33.0 & 31.6 & 41.6 & 46.7 & 54.4 & 65.2 & 70.6 & 72.0 & 63.9 & 56.1 & 45.6 & 39.6 & 51.7 \\ 1974 & 34.4 & 30.4 & 38.6 & 47.1 & 52.7 & 62.9 & 69.6 & 72.0 & 64.5 & 51.3 & 46.6 & 39.1 & 50.8 \\ 1975 & 36.5 & 33.1 & 36.7 & 42.9 & 55.9 & 64.0 & 71.7 & 71.3 & 62.9 & - & 50.5 & 34.3 & - \\ 1976 & 27.5 & 37.8 & 40.9 & 52.0 & 58.1 & 69.4 & 68.8 & 68.8 & 62.6 & 51.1 & 40.0 & 29.7 & 50.5 \\ 1977 & 22.6 & 28.6 & 40.1 & 46.4 & 56.0 & 63.5 & 71.1 & 70.9 & 64.1 & 55.1 & 47.9 & 35.8 & 50.2 \\ 1978 & 29.2 & 26.4 & 34.2 & 43.9 & 53.3 & 63.8 & 67.9 & 71.0 & 61.3 & 54.1 & 46.4 & 38.0 & 49.1 \\ 1979 & 33.1 & 22.1 & 40.0 & 45.3 & 57.2 & 63.2 & 71.0 & 70.6 & 65.2 & 54.7 & 51.4 & 40.8 & 51.2 \\ 1980 & 33.3 & 29.9 & 38.2 & 48.0 & 57.1 & 63.2 & 72.7 & 71.9 & 64.8 & 52.8 & 42.9 & 32.1 & 50.6 \\ 1981 & 23.9 & 35.1 & 35.8 & 46.2 & 55.0 & 65.0 & 70.8 & 68.3 & 62.4 & 51.9 & 44.9 & 35.8 & 49.6 \\ 1982 & 26.3 & 32.3 & 37.1 & 43.0 & 54.7 & 61.5 & 71.6 & 67.4 & 62.2 & 54.6 & 48.8 & 41.6 & 50.1 \\ 1983 & 34.2 & 34.7 & 40.7 & 47.5 & 54.2 & 65.5 & 71.5 & 69.9 & 67.1 & 56.3 & 49.2 & 35.2 & 52.2 \\ 1984 & 30.1 & 37.9 & 34.6 & 45.9 & 55.9 & 66.0 & 69.7 & 72.5 & 63.6 & 58.3 & 47.2 & 43.9 & 52.1 \\ 1985 & - & 32.8 & 39.3 & 47.8 & 56.3 & 62.6 & 70.5 & 70.8 & 65.9 & 57.2 & 50.3 & 36.9 & 51.7 \\ 1986 & 33.9 & 31.7 & 39.3 & 48.0 & 56.0 & 63.3 & 68.7 & 68.6 & 62.0 & 55.3 & 45.2 & 38.9 & 50.9 \\ 1987 & 32.6 & 30.6 & 39.3 & 46.4 & 54.6 & 64.2 & 70.2 & 68.8 & 64.4 & 53.2 & 45.2 & 38.1 & 50.6 \\ 1988 & 30.1 & 32.7 & 38.4 & 45.6 & 54.0 & 62.7 & 70.7 & 71.0 & 62.8 & 51.8 & 47.8 & 36.7 & 50.4 \\ 1989 & 36.3 & - & - & 5.0 & 56.0 & 66.1 & 68.5 & 69.9 & 64.8 & 54.8 & 44.0 & 26.6 & \\ \text { Mean } & 30.6 & 31.5 & 37.8 & 45.9 & 55.1 & 64.0 & 70.3 & 70.4 & 64.0 & 54.5 & 46.4 & 36.6 & 50.6\end{array}$

Source: National Oceanic and Atmospheric Administration (NOAA) 1990

The shoulder months of April, May, September, October, and November are also

very important however, since high golf play during these months would be the key to the golf courses success. The climate then, is well suited to golf play during these shoulder months and a nine month season should be the norm for the island, with the high possibility of a mild winter extending this season during certain years.

\subsection{Topography}

Topographical analysis of a proposed site is important in golf development. Severe topography can be a major constraint to development. The greater the severity of slope on a parcel, the higher the cost involved in creating a topographically acceptable landscape. 
Block Island's topography consists mainly of gently rolling hills with few areas on the Island exceeding $15 \%$ slope. Seaside bluffs and a few inland areas exceed this figure, but these slopes are considered to be an asset to the Island's beauty and are as such, valuable commodities to be preserved.

The sites being examined for golf development for the most part fall well within the $15 \%-20 \%$ limitation needed for golf development. The sites topographical features will be examined individually.

\subsubsection{Northern Site}

The Northern site is comprised of a gently rolling landscape with average slopes not exceeding $5 \%$. The area's topography is well suited to the links development, and it would be quite possible to design a layout on this property with minimal alteration to the existing topography. The only area where modification may be required would be in the area of drainage swail design and possible pond construction. This area's topography then, would be considered highly feasible for golf course development with little or no constraints to development. (See Figure 7, showing topography of the Northern site)

\subsubsection{Southern Site}

The Southern site is characterized by a rolling landscape with slightly higher average slopes than its Northern counterpart. Average slopes in this area fall in the $8 \%$ range. The site does have portions of its area that approach the $20 \%$ cutoff, but 
these portions fall within an area known as the Enchanted Forest; a protected site that cannot be developed. The rest of the site shows no constraints to development, although there may be a greater need for modification to the topography of the site, which would mean that the development cost would potentially be higher than at the Northern site. (See Figure 8 for a Topographical map of the Southern site)

\subsection{Soils}

The need to examine the soils of a projected golf course development is important in determining feasibility. The USDA Soil Survey Manual was utilized to determine the types of soils and their approximate percentages within both the Northern and Southern sites. Along with this, an analysis of the soils suitability for golf fairway development according to USDA standards is included. (Table 3 and 4)

An analysis of the data would seem to suggest that there are enough suitable soils within each site to consider them feasible for development. The location of the soils within each site, however, play an important role in determining if the sites have enough suitable soils concentrated in the proper locations within the parcel. (Figures

9 and 10 show the locations of the various soil types within the proposed sites). 


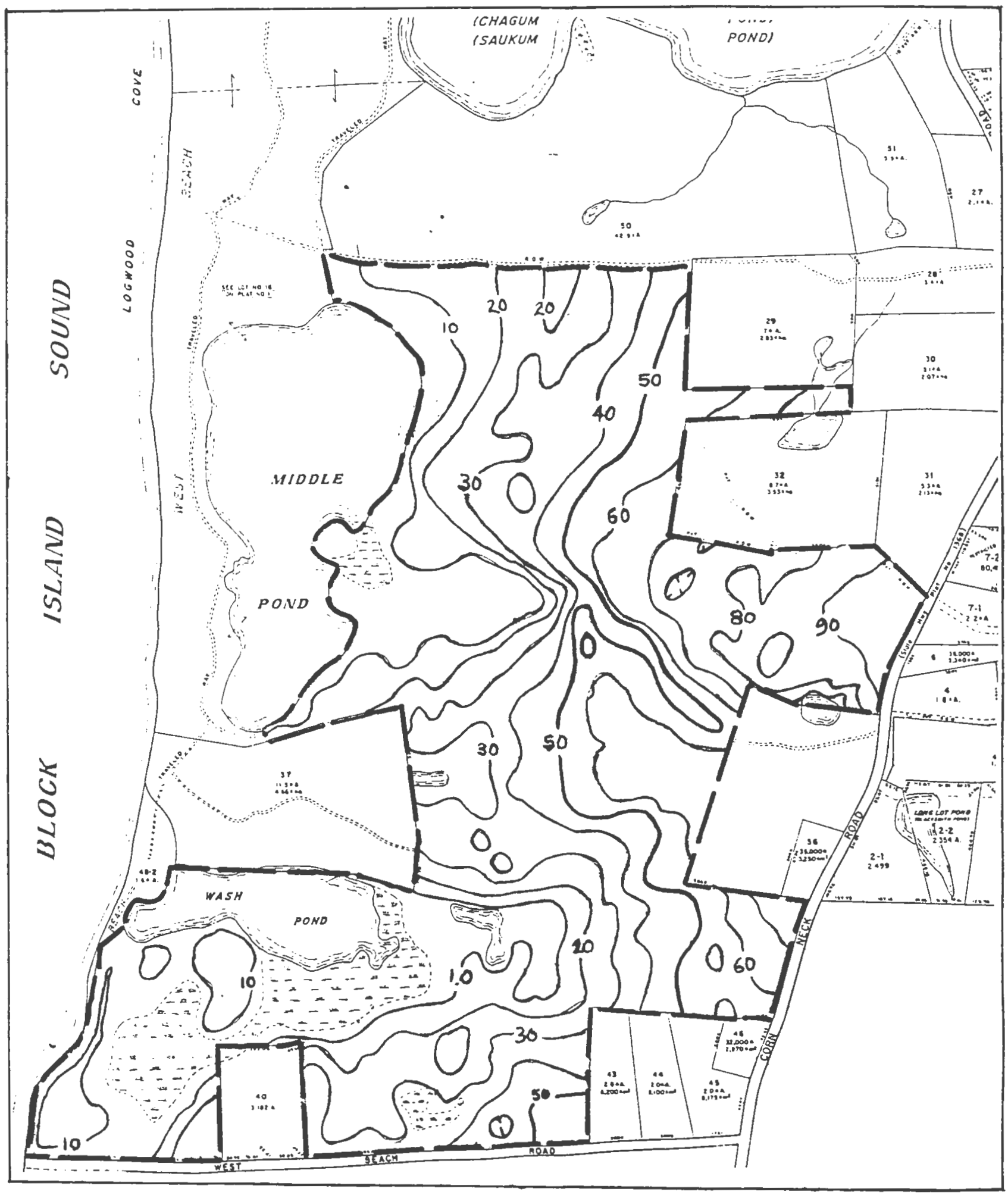

Figure 7. Topography of Northern Site, Showing Ten Foot Intervals 


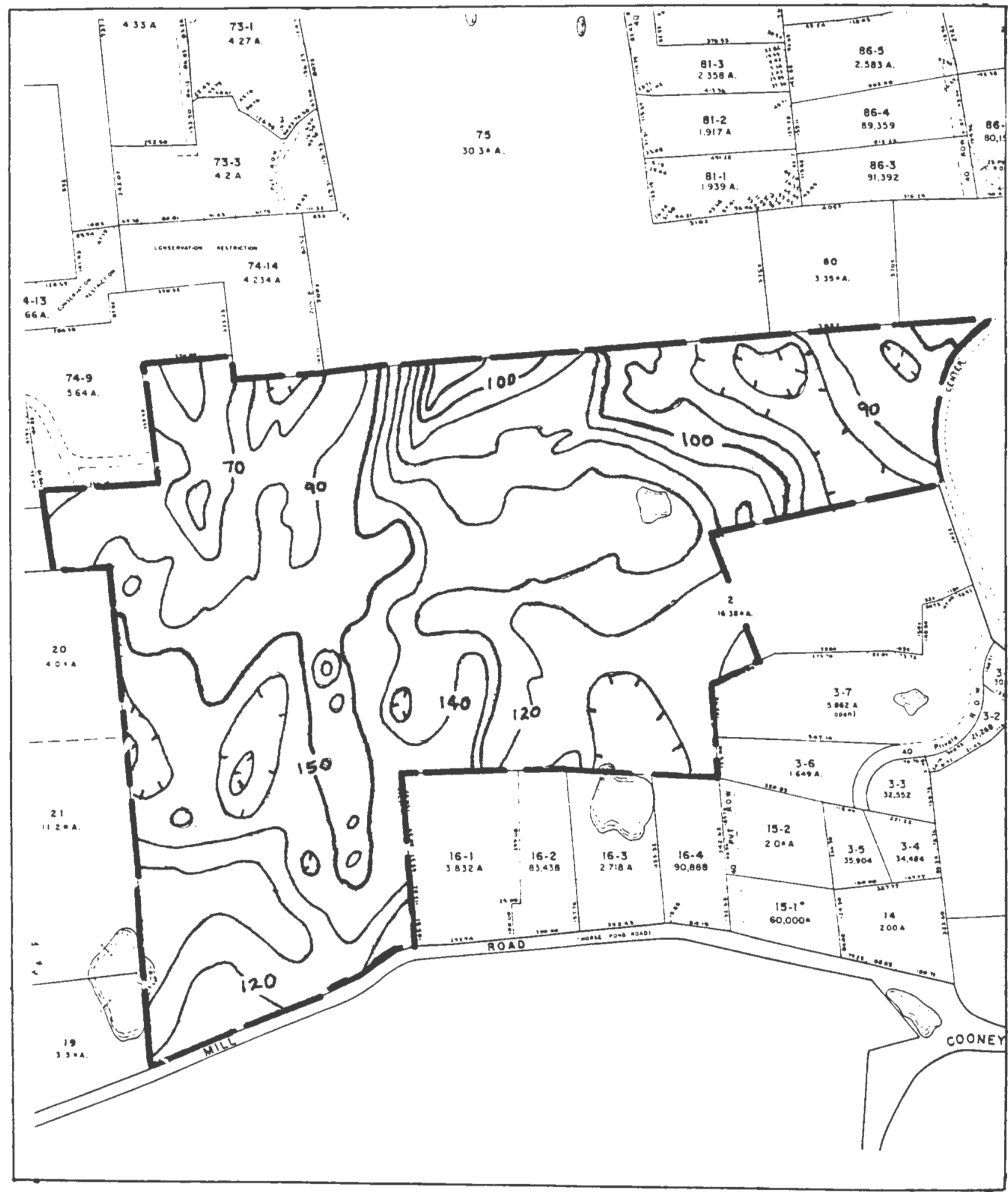

Figure 8. Topography of Southern Site, Showing Ten Foot Intervals

Source: USGA, Block Island Quadrangle 


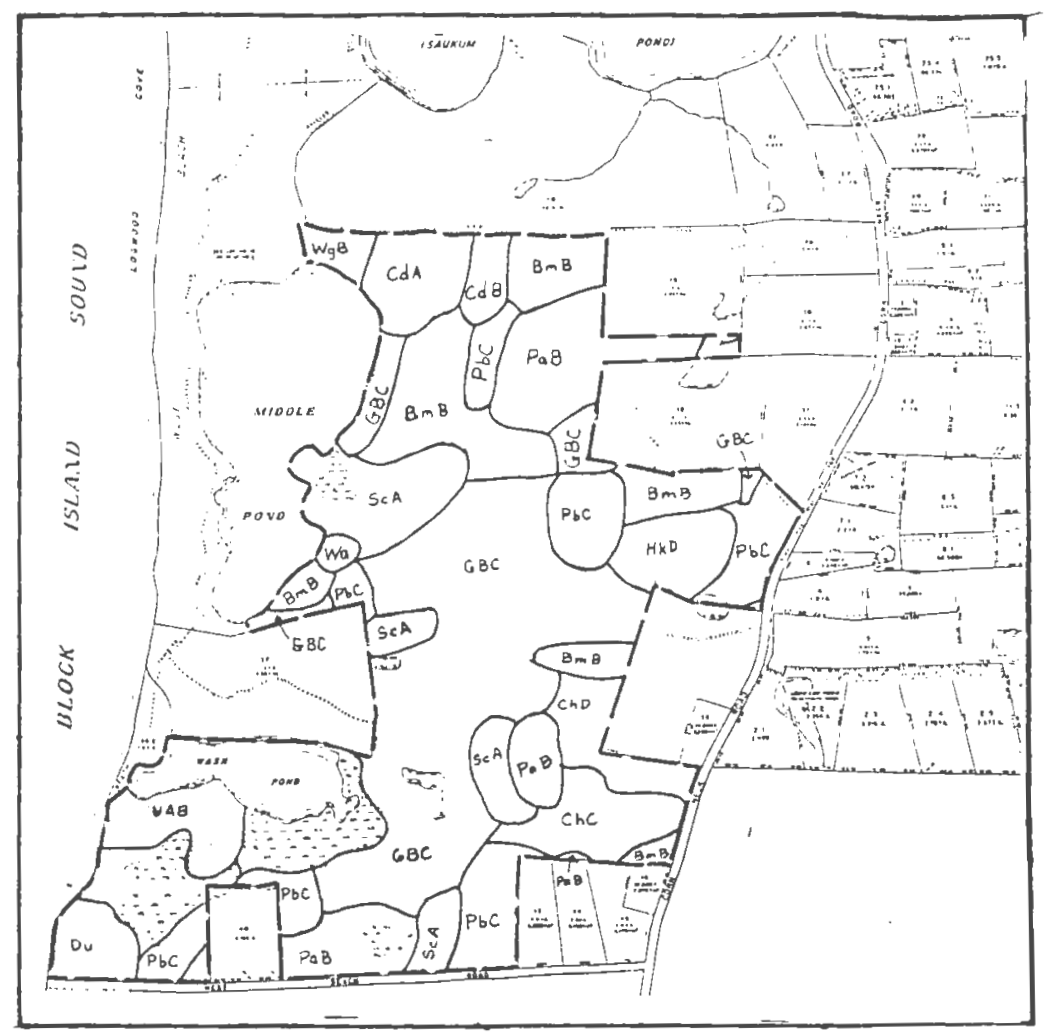

Figure 9. Soil types and their locations, Northem Site.

Source: USDA Soil Survey Manual

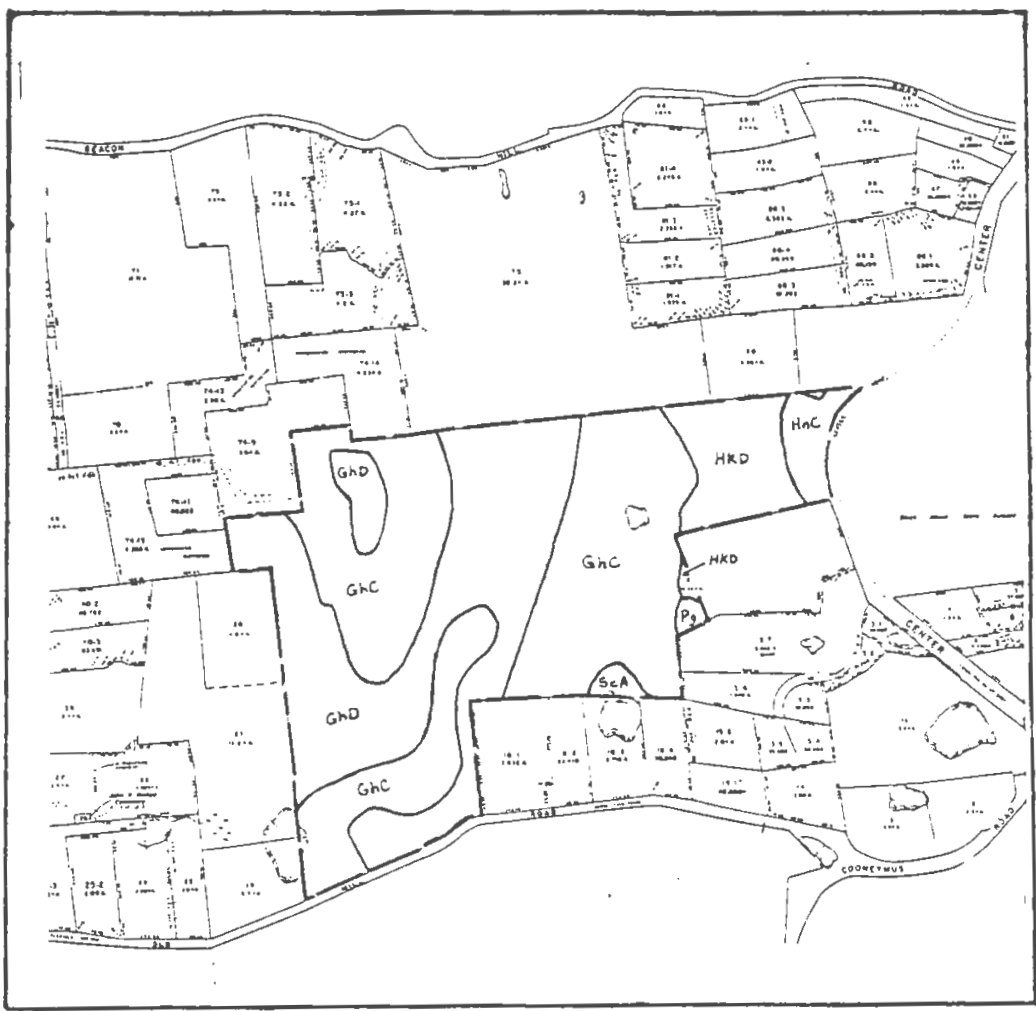

Figure 10. Soil types and their locations, Southem Site.

Source: USDA Soil Survey Manual 
Table 3

SOIL TYPE

\begin{tabular}{l|}
$G B C$ \\
$B m B$ \\
$U A B$ \\
$\mathrm{PbC}$ \\
$\mathrm{PaB}$ \\
$\mathrm{Wa}$ \\
$\mathrm{SCA}$ \\
$\mathrm{CdA}$ \\
$\mathrm{Mk}$ \\
$\mathrm{WgB}$ \\
$\mathrm{DU}$ \\
$\mathrm{ChD}$ \\
$\mathrm{HkD}$ \\
$\mathrm{CdB}$
\end{tabular}

Suitability of Soils - Northern Site APPROXIMATE PERCENTAGE * SUITABILITY FOR DEVELOPMENT**

- Estimates of percentages are approximate due to the multiple land acquisition possibilities that exist. All soils that fell within the general area of the proposed sites were included.

* Suitability is based on the ability to sustain golf fairways as denoted in USDA Soil Survey of Rhode Island, Table 22.

$34 \%$ of the soils show slight constraints to golf development.

$35 \%$ of the soils show moderate constraints to golf development

$31 \%$ of the soils show severe constraints to golf development.

Source: CPAD study

Table 4

\begin{tabular}{l|r} 
GhC & $60 \%$ \\
GhD & $20 \%$ \\
HkD & $10 \%$ \\
HnC & $6 \%$ \\
SCA & $3 \%$ \\
Pg & $1 \%$
\end{tabular}

\section{SOIL TYPE}

$\mathrm{Pg}$
Moderate: Slope

Slight

Moderate: Large Stones

slight

Severe: Hetness

slight

slight

Severe: Hetness

Severe: Too Sandy

Severe: slope

Severe: slope

slight

\section{Suitability Of Soils - Southern Site} APPROXIMATE PERCENTAGE * SUITABILITY FOR DEVELOPMENT **
Moderate: slope

Severe: Slope

Severe: slope

Moderate: Slope

Slight

Gravel Pit

* Estimates of percentages are approximate due to the multiple land acquisition possibilities that exist. All soils that fell within the general area of the proposed sites were included.

* Suitability is besed on the ability to sustain golf fairways as denoted in USDA Soil Survey of Rhode Island, Table 22.

3\% of the soils show slight constaints to golf development.

$66 \%$ of the soils show moderate constraints to golf development.

$31 \%$ of the soils show severe constraints to golf development.

Source: CPAD Study

The Northern sites slight and moderately constrained soils are well concentrated 
for the development of a reasonable golf layout. Large areas of slight and moderately constrained soils such as Gloucester (GBC), Bridgehampton (BmB), Scio (ScA) and Paxton $(\mathrm{PaB})$, are concentrated in the central portion of the site. Many of the slight and moderate soils abut one another, making it much easier to design challenging golf layouts. From this standpoint then, the Northern site shows little constraint to golf development.

The Southern site would seem to have enough adequate soils available to develop a golf course. But upon examination of the soils map, we see a large concentration of severely constrained soils (Gloucester, GhD) running through the center of the site. This concentration would make the design of a golf layout much more difficult to achieve. Constraints to this site are fairly high and poor soil concentration would make this area more difficult to develop than the Northern site.

\subsection{Wildlife}

New Shoreham is an important refuge for a wide variety of wildlife. Block Island is in the Atlantic migratory flyway, and thus an incredible array of bird species visit the Island during their migratory flights in the spring and fall. It is not surprising then, that over 60 bird species are commonly sighted during these seasons. A large proportion of less frequently observed birds have been logged as well. The Island also has several mammalian species, two of which are native to the Island. Several endangered species are also found on Block Island, more in fact than anywhere else in Rhode Island. 
Endangered

species protection will

play an important role

in golf feasibility,

since it would be

difficult to build a

course on land where

endangered species

are found. A list of

wildlife that would be

expected to be found

on the sites can be

seen in Table $\mathbf{5}$.

Endangered species

are marked with an

asterisk.

Uponexamination

of Table 5, we find

one species, the

American burying

beetle
TABIE 5 Wildlife Species Indigenous To The Sites

Mammals:

White Tailed Deer

Block Island Meadow Vole *

Cottontail Rabbit (Recently Introduced)

Rat

Field Mouse

Birds:

Loons (2 species) Green Winged Teal

Grebes ( 3 species) Black Duck

Northern Gannet Mallard

Cormorant ( 2 species) Canvasback

American Bittern *

Herons (2 species)

Great Egret

Mute Swan

Snow Goose

Brant

Canadien Goose

Wood Duck

American Kestral

Rail

Killdeer

Gulls ( 6 species)

Razorbill

Owl (4 species)

Woodpeckers ( 3 species)

Horned Lark

Common crow

Scaup (2 species)

Common Eider

Scoter ( 3 species)

Bufflehead

Merganser ( 3 species)

Ruddy Duck

Northern Harrier *

Hawks ( 3 species)

Pheasant

coot

Upland Sandpiper *

Dovekie

Mourning Dove

King $f$ isher

Wren ( 4 Species)

Thrush

Catbird

Waxwing

Starling

Cardinal

Sparrow (12 species)

Eastern Meadowlark

Finch ( 2 species)

Northern Flicker

Blue Jay

Nuthatch (2 species)

Eastern Bluebird

American Robin

Mockingbird

shrike

Warblers ( 3 species)

Rufous Sided Towhee

Slate Colored Junco

Common Grackle

Siskin

Insects:

American Burying Beetle *

Herptiles:

Snapping Turtle

Spotted Turtle *

painted Turtle

Fish:

Largemouth Bass

Bluegill

Chain Pickeral

Source: CPAD Study, Block Island Christmas Bird Survey, 1990

(Nicrophorus americanus) on the endangered species list. Part of the limited range 
of this insect falls within the boundary of the proposed Southern site. This would be considered a high constraint to development since modification of the site could potentially destroy the animals habitat. Approval to develop this area would be difficult to obtain based on this constraint. Two other rare species, the American Bittern and the Northern Harrier, would also be expected to visit the sites occasionally. The habitats of these animals could be temporarily destroyed due to course construction, but these species would be expected to return to the sites once the course has grown back in and established itself, especially if coastal wetland features are protected by a 200 foot buffer. In addition the links design would mean only minimal alteration to the overall habitat, and it is expected that a large proportion of Block Island's wildlife could actually thrive on the course, especially if existing vegetation is preserved as much as possible.

\subsection{Vegetation}

The proposed golf sites vegetation is typical of many seaside areas. The general diversity of plant life is rather low, the areas however, are ecologically valuable even considering their rather limited vegetation varieties.

An analysis of existing vegetation on the sites was accomplished through site walks as well as a review of literature discussing the various plant species encountered in Rhode Island coastal areas and on Block Island. A listing of vegetation encountered at the individual sites can be seen in Table 6.

The vegetative types would be considered a benefit to the development of a golf 
course. The varieties fit in well with the links concept. There should be no constraints in the development of the golf course.

Table 6 Vegetation: Northern Site

Vegetation: Southern Site

Trees:

Japanese Black Pine

Crabapple

Apple (abandoned orchard)

Red Maple

Shrubs:

Bayberry

Low Bush Blueberry

Seashore Rose

Inkberry

Grasses:

Dunegrass

Fescue grasses

Reed Grass (phragmites)

Saltmarsh Cordgrass (spartina)
Trees:

Japanese Black Pine

Red Pine

Wild Cherry

Red Maple

Shrub Willow

Shrubs:

Bayberry

Inkberry

Low Bush Blueberry

High Bush Blueberry

Grasses:

Fescue Grasses

Beard Grass

Source: CPAD Site Survey, Rhode Island Dept. of Environmental Management

\subsection{Ground and Surface Water Resources}

It is obvious that a golf course cannot operate without water. Water adequate for use as an irrigation source can come from two places: surface (water in the form of ponds) and Groundwater (water coming from perched water sources beneath the surface of Block Island). 


\subsubsection{Surface Water}

Block Island has many freshwater surface features ranging in size from several acres to small 10 foot wide mud holes that become seasonally dry. There are several ponds located on or near the sites being evaluated for golf development. Evaluation of certain ponds show that some could be considered usable as sources of irrigation water for a potential golf course. The main constraint for the use of existing ponds in this case is Chloride. Concentrations of 1500 parts per million can have a significant negative impact on turfgrasses (Turgeon, 1980). Therefore all sources must have levels significantly lower than this figure in order to be considered usable as irrigation water. Levels of 500 to 600 parts per million would be considered the maximum allowable concentrations for this use (Turgeon, 1980).

The Northern site has only one large natural pond marginally capable of supplying suitable water to the potential golf site (Middle Pond, $500 \mathrm{ppm}$ chloride) but even this level is at the upper limits of usefulness. Wash Pond is totally unsuitable for use due to its brackish condition and extremely high levels of Chloride. These two ponds would not be viable sources at any rate since as mentioned earlier, the Coastal Resource Management Council (CRMC) would undoubtedly consider these ponds and their associated wetlands as valuable and delicate estuarine resources; and would most definit - designate these areas as coastal wetlands with a surrounding 200 foot buffer.

Small kettle hole ponds on the site are untested but it is probable these ponds could provide water of adequate quality for irrigation. These ponds would require 
modification to make them usable as irrigation ponds (ie. increasing their size).

The Southern sites ponds are well within acceptable limitations in terms of chloride concentrations, but since they are rather small they are rather limited as a sole source of water for golf irrigation and would require modification as in the case of the kettle ponds at the Northern site.

In both cases, if surface water were to be chosen as the source of irrigation, it would be necessary to design man made ponds on the golf course sites. Wash and Middle ponds cannot be considered as sources of irrigation water for a variety of previously mentioned reasons, therefore one or more large man made ponds installed further inland on the site would be required to provide water and would assure protection from salt contamination as well as provide additional water holes for the golf course design. In addition these ponds could be designed to the exact specifications required to adequately maintain the watering needs of the course. As an alternative to totally man made ponds, the small kettle ponds on these sites could be modified and made larger in order to make them usable as irrigation ponds.

The Southern sites surface water sources, as mentioned earlier, are small, and although they could possibly be incorporated into a working irrigation system through modification, the installation of man made ponds would probably be the best alternative for this site as well. 


\subsubsection{Groundwater}

Surface water is one option available when examining the sites for a potential water source. Groundwater must also be examined to determine if it would be suitable for use within the areas in question.

As is the case with surface water, chloride is a major concern. A perched water table exists under both sites under consideration, but groundwater well tests show inadequate quantities of water exist in the Northern site to serve the irrigation needs of a typical golf course.

The Southern site is over some of the most productive groundwater resources on the Island (Rhode Island Water Resources Coordinating Board (RIWRCB), 1964) and thus the possibility of using groundwater here is more realistic.

Groundwater resources in the Northern site would be unable to supply the 300 to 500 gallons per minute necessary to adequately maintain a typical golf course. Climactic conditions in combination with the links style design, however, could substantially reduce water consumption on the course and it is possible that the golf course could be adequately maintained with considerably less water than the typical course requirements of 300 to 500 gallons per minute. It would be wise, nevertheless, to provide an irrigation system that could maintain the greens tees and fairways adequately during droughty periods that could possibly occur.

Although the yield of the one test well in the Southern site is only ten gallons per minute, the Island's most productive groundwater resource are located under this site and it would be quite possible to find areas on the parcel that could provide the 
necessary water to irrigate the course (See Figure 11 and 12, showing groundwater resource availability at the Northern and Southern Sites). Groundwater chloride is not a constraint in terms of irrigation use for both the Northern and Southern sites.

\subsubsection{Findings}

\section{Northern Site}

Surface water would probably be the best method for obtaining irrigation water for the Northern site since groundwater test wells on the site only yielded 10 to 12 gallons per minute (RIWRCB, 1964). The links design, coupled with the climate of the Island could reduce watering needs and thus make a groundwater irrigation system a marginal possibility. The area would require a number of wells to be drilled on the more productive groundwater resources on the eastern side of the property. Wells could be utilized as a water source for the clubhouse and maintenance building, since the water demand for these facilities would be within acceptable limits for domestic use.

\section{Southern Site}

The Southern site could utilize either surface or groundwater resources or perhaps a combination of both. Man made ponds could be incorporated into the golf course design and be located in areas that would provide challenging holes for play or perhaps the small natural ponds could be modified for use. As mentioned earlier this site is located above the most productive groundwater resources on the Island. Consequently, water availability would not be a major constraint for this site. 


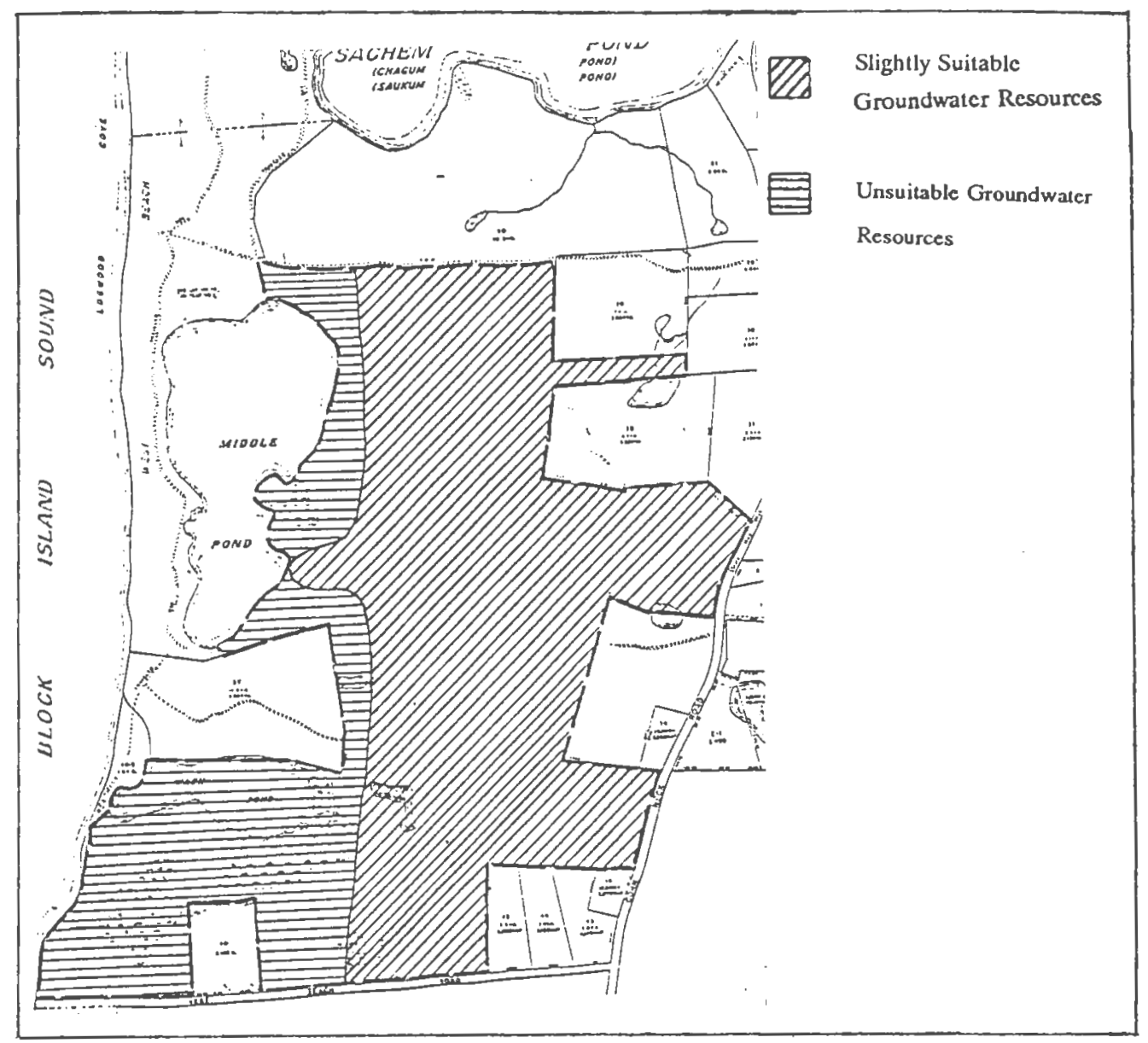

Figure 11. Groundwater Resource Availability, Northern Site.

Source: Rhode Island Watcr Resources Coordinating Board

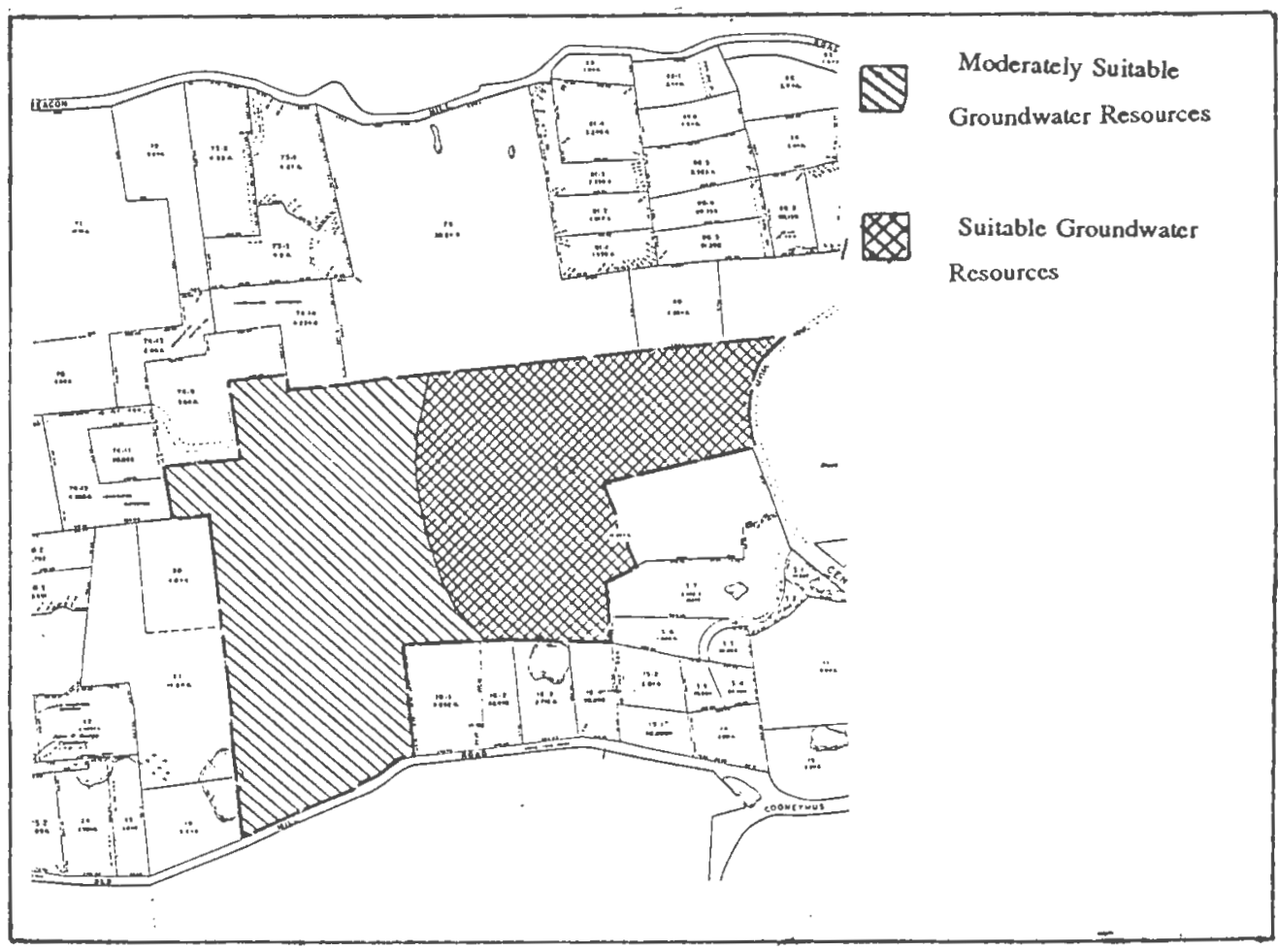

Figure 12. Groundwater Resource Availability, Southern Site

Source: Rhode Island Water Resources Coordinating Board, 1964 


\subsubsection{Possible Impacts to Surface and Groundwater}

The groundwater resources of Block Island are the sole source of drinking water currently available to the residents of Block Island. Many surface water features on the Island are in pristine condition as well. It is therefore very important that these water sources are not contaminated.

One concern that is often voiced when golf courses are proposed, is the potential for pesticides and fertilizers to leach into the groundwater or runoff into surface water features. These concerns are valid and must be addressed in determining feasibility.

All golf courses require pesticides and fertilizers to some degree in order to maintain adequate playing conditions, particularly on the greens, tees and fairways. The links type golf course is better suited to thrive with less fertilizers and pesticides than the more traditional American style golf courses. The links design recommended in this feasibility study would provide a playing space that would minimize the number of areas requiring pesticides and fertilizers, thus reducing the amounts of potential leachates into the groundwater.

The majority of pesticides and fertilizers would be applied to tees and greens; lesser quantities, perhaps only one slow release fertilizer application would be applied to fairways. The typical, rugged look of a links course means that it can thrive under these minimal application conditions.

In studies conducted by various research groups it was found that impacts to groundwater by fertilizers and pesticides could be minimized if proper management 
practices were in place. In a recently completed study conducted by The Cape Cod Economic Development Commission in conjunction with the Environmental Protection Agency it was found that pesticide and fertilizer intrusion into the groundwater were minimal. The study noted that seven of the tested turf pesticides were never detected in the groundwater. In addition, no registered pesticides were detected at toxilogically significant concentrations. The study also showed that lower nitrate concentrations resulted when less nitrogen, slow release nitrogen or a combination of both were used (Cohen, 1990).

In other research conducted at the University of Massachusetts it was determined that runoff and leaching could be reduced to near zero when pesticides and fertilizers are applied on dense turf with a good thatch layer (Cooper, 1990).

Cornell University studies concluded that the use of slow release nitrogen sources in small doses (commonly referred to as "spoon feeding") could reduce intrusion of nitrates into groundwater nearly entirely (Petrovic, 1989).

All of these studies stressed the need for proper management practices in reducing the potential for contamination. Several techniques to accomplish this are mentioned in the studies.

It must be remembered that these tests were conducted on courses with standard pesticide and fertilizer applications as well; Block Island's links golf course would probably receive significantly lower quantities than the courses tested in the Cape Cod study. 


\subsubsection{Fertilizer Requirements For The Golf Course}

The amounts of fertilizer needed to maintain the various areas of golf course turf (Creeping Bentgrasses) is shown in Table 7.

These fertilizer requirements are for creeping bentgrass, a variety which generally requires higher levels of fertilizer in order to thrive. Although creeping bentgrass would most likely be used on greens and tees, it is likely that fairways and rough on a links course would utilize grass varieties that are more drought tolerant and disease resistant. Table 8 shows varieties that would be well suited to rough and fairways on a links type course.

TABLE 7 Typical Yearly Nitrogen Fertilizer Program For Golf Courses

$\begin{array}{lcc}\text { Location } & \begin{array}{c}\text { Creeping Bentgrass } \\ \text { lbs N/1,000 ft/yr }\end{array} & \begin{array}{c}\text { Single Application Rate } \\ \text { lbs N/1000 sq. } \mathrm{ft}\end{array} \\ \text { Green } & 2 \text { to } 6 \mathrm{lbs} & 0.1 \text { to } 1.0 \mathrm{lbs} \\ \text { Tees } & 2 \text { to } 6 \mathrm{lbs} & 0.1 \text { to } 1.0 \mathrm{lbs} \\ \text { Fairways } & 1 \text { to } 4 \mathrm{lbs} & 0.5 \text { to } 1.0 \mathrm{lbs} \\ \text { Roughs } & 1 \text { to } 2 \mathrm{lbs} & -\end{array}$

Source: Comell University, 1988

Improved strains of some of the varieties shown in Table 8 have been developed. These improved strains are more drought tolerant and are less susceptible to diseases. Perennial Ryegrasses, Tall Fescues and Kentucky Bluegrasses are just three varieties that have improved strains available. 
TABLE 8

Grasses Suitable For Use On Links Fairways and Roughs

\begin{tabular}{lll} 
Variety & Best Use & Nitrogen Requirements \\
\hline Red Fescue & Roughs & Low \\
Chewings Fescue & Roughs & Low \\
Hard Fescue & Roughs & Low \\
Tall Fescue & Roughs & Low \\
Rough Bluegrass & Fairways & Mod/Low \\
Kentucky Bluegrass & Fairways/Rough & Mod \\
Crested Wheatgrass & Fairways/Rough & Low \\
Perennial Ryegrass & Roughs & Mod
\end{tabular}

Source: AJ. Turgeon, Turfgrass Management, 1980

\subsection{Viewsheds}

Part of what makes Block Island unique are the beautiful viewsheds that exist on all corners of the Island. The Comprehensive Plan currently being developed, places a strong importance on the preservation of these unique viewsheds.

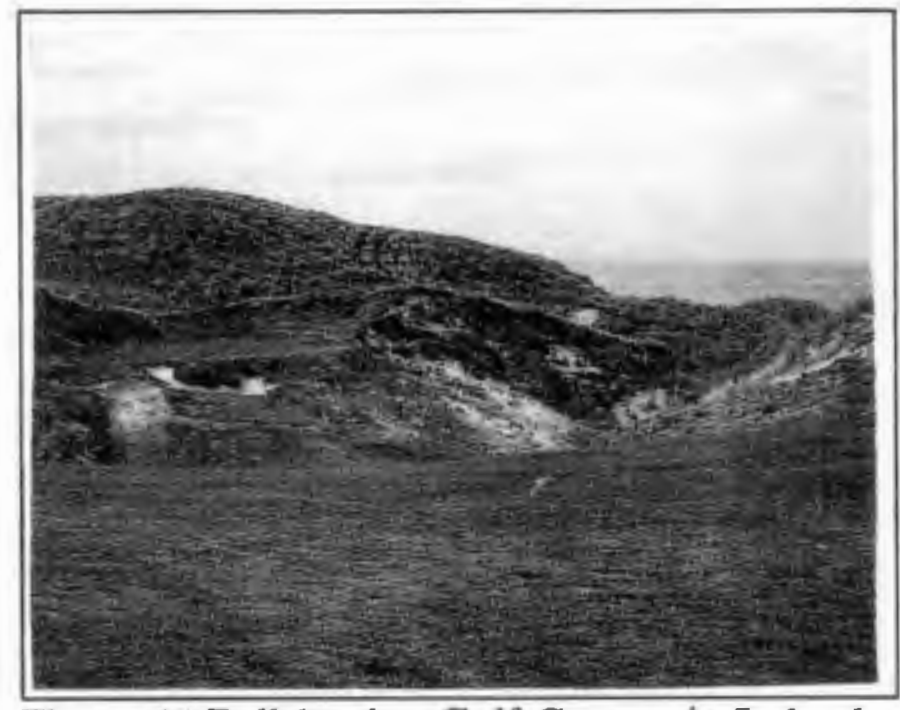

Figure 13 Ballybunion Golf Course, in Ireland. Source: Golf Course Superintendents Asoociation of America, 1985.

A links golf course would tend to preserve viewsheds, especially a links type course that would tend to meld into its environment, as illustrated in Figure 13. This Irish course shows how well a links style course could fit into the existing landscape, thus reducing the risk of 
viewshed destruction. The development of residential properties on either of the proposed sites would do little to preserve these valuable viewsheds.

\subsection{Findings}

The results of the environmental assessment show the following:

1. The links design is the best design option for the Island since it most closely matches the character and scenery of Block Island.

2. Climatological History- The general climate is conducive to a nine month golf season and perhaps during certain years, longer seasons.

3. Topography- Both sites have topography that is acceptable and within the limitations for golf development. The topography of the sites would actually add to the visual enhancement of the golf course links concept.

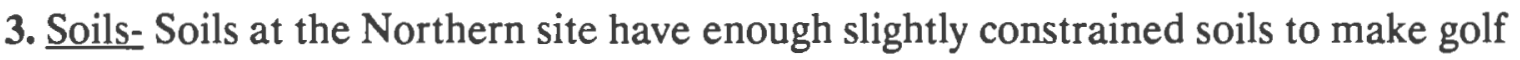
development feasible. In addition, these soils adjoin each other making the design of golf layouts easier.

Soils at the Southern Site show higher constraints due to the high amounts of highly constrained soils as well as their poor location within the site. Golf layouts would be more difficult to design due to the soil difficulties in this area.

4. Wildlife- Although some displacement of wildlife would occur as the golf course was developed, longterm impacts would be minimal. After construction is complete, it is expected that most wildlife species would repopulate the areas. An endangered animal at the Southern site (the American Burying Beetle) would 
place extreme constraints to development of this area, since federal regulations are most stringent in the protection of any form of endangered wildlife. Wildlife constraints, then, would be lower at the Northern site.

5. Vegetation- Vegetation at both sites is conducive to golf links development, and should pose no constraints to the development of the course. The Southern Site would, however, require greater vegetation removal than the Northern Site, thus creating greater development costs.

6. Surface and Groundwater- The Northern site's groundwater resources are probably not adequate to produce enough water to operate the golf course, although the links design would lower overall water demand to the point where it could perhaps be considered. The development of surface ponds on the Eastern side of the parcel would probably be the best option in providing water for the course, and may be the best option in the long run.

The Southern sites groundwater resources could potentially provide water for irrigation. The option of developing surface ponds could also be utilized here. Overall, water availabilty should not pose a significant constraint if the links design is utilized.

7. Pesticide and Fertilizer Impacts- Studies have shown that proper maintenance practices can reduce pesticide and fertilizer leaching into groundwater, to the point where no significant impacts would occur. In addition, the links concept generally would use less fertilizers and pesticides in the overall maintenance of the course. 
8. Viewsheds- Utilizing the links design, viewshed preservation would not be significantly altered. 


\section{REFERENCES FOR CHAPTER FOUR}

Cohen, Stuart Z.; The Cape Cod Study, Golf Course Management Magazine, February, 1990. Pg 26.

Cooper, Richard; Evaluating the Runoff and Leaching Potential of Turfgrass Pesticides, Golf Course Management Magazine, February, 1990.

The Graduate Curriculum in Community Planning and Area Development; Economic and Environmental Strategies for the Town of New Shoreham, Cooperative Extension Service, December, 1990.

Kupa, John J.; Vegetation Map. Block Island, Rhode Island, 1972.

Petrovic, A. Martin; Golf Course Management and Nitrates in Groundwater, Golf Course Management Magazine, September, 1989. Pg. 54.

Rhode Island Water Resources Coordinating Board; Groundwater Resources of Block Island, Rhode Island, Geological Bulletin No. 14, 1964.

Turgeon, A.J.; Turfgrass Management, Reston, Virginia: Reston Publishing Company, 1980.

USDA Soil Conservation Service; Soil Survey of Rhode Island, July 1981.

Watschke, Thomas L.; The Environmental Fate of Pesticides, Golf Course Management Magazine, February, 1990. 
CHAPTER FIVE - FINANCIAL ASSESSMENT 


\section{Introduction}

This section of the study will begin by outlining the various financing options that are available for golf course development. Next, a model course operating under similar circumstances to what would be expected on Block Island will be examined to help strengthen the idea that golf can succeed in an isolated Island environment.

Golf course construction estimates will be provided, as well as information on the costs and revenues that would be expected on the golf course. All estimates will utilize the demand and supply information that was calculated in Chapter 3 of this study. Finally, other economic issues such as tourist attraction to the golf site, transportation, employment possibilities, and dealing with additional tourist will be covered.

\subsection{Ownership and Financing Options}

There are a variety of financing options available to golf course development. The options are based on the type of development that is proposed. Several types of courses are possible. These include:

1. The municipally owned and operated golf course - This type of course would fall completely under town jurisdiction. All elements of financing, construction and management would be the town's responsibility.

2. A course that is leased by the town to a private developer - In this case the land is owned by the town, but is leased to a golf management group that would develop and manage the course over a specified period. In some instances after 
an agreed lease period (perhaps 20 years) the course management responsibilities are turned over to the municipality.

3. A privately owned and operated daily fee course- This course would be financed, constructed and managed by either an individual, a group, or a limited partnership. This option is more risky from an open space preservation standpoint, since the private owner could at some point in the future, liquidate the property for residential development, thus losing open space land; as in the case of Vaill Golf Course.

These three options show the greatest promise for golf development on the Island. Other options exist, such as a private, members only type course, but this option is not likely to occur on Block Island and as a result will not be covered in this study. Financing options for the establishment of a golf course depend on who is developing the project. If the town were to take on the development of the course the following options are available:

General Obligation Bond- Many communities place golf in their long range recreational or open space master plans. In this case voter approval of a general obligation bond would provide funding for the development of a course. The fact that Block Island would be developing the course as a way of preserving open space would be a particular draw for voter approval of this type of funding option.

Revenue Bond- Revenue bonds do not require a vote of the public in order to be approved. This funding option is issued and backed by the town's credit rating and 
revenues from designated sources of municipal income. A revenue bond may be used to underwrite earlier costs of land acquisition, so a lease operator who has contracted to build and operate the course can get started. Private agencies such as land banks can also receive Revenue Bonds. This financing option was chosen by the Nantucket Land Bank in acquiring an already existing golf course on the Island (See section 5.2 for a discussion on Nantucket's Miacomet Golf Course).

Land Lease-Instead of leasing a facility to a golf management group for construction and operation, the town might elect to lease to a company that would develop the course and then lease it back to the municipality. One advantage to this option is that no debt service appears on the municipality balance sheet, and when the lease expires, the town will again own the land free and clear. There are companies that specialize in this type of option, that are developing courses nationwide. Many financial groups have been very successful in developing courses for municipalities in this manner.

Friendly Lease- There may be situations where an individual property owner may wish to protect their land from development but are amenable to a golf facility on their property that would maintain open space. In this case, the land may be leased to the municipality with a minimum up front payment. This option may also include the development of easements through certain parcels of land. In this case, no lease payments would be required. 
Privately owned daily fee golf course developers can utilize the following financing options:

Conventional Loans- This option is usually reserved for real estate developments associated with golf courses. Although this is not likely on Block Island, it is possible that a loan from a bank or insurance company could be arranged.

Limited Partnerships- In some instances, a small group of businessmen may show interest in golf development, and form a limited partnership. Using elements such as a business plan outlining profit return it would be possible to receive financial support from a limited partnership group.

If the town intends to own and manage the property, obligation or revenue bonds would be the best option, if they intend to lease the property to a management and/or development group, business partnerships or conventional loans would probably be the options of choice. The land lease option could also show promise, as well. Other options such as the friendly lease may also avail themselves, and could be utilized effectively in the development of the course.

In any of the above stated cases, the development of a plan to use local hotels and inns to create golf/hotel package options would be advised in order to attract tourist golf during the shoulder months.

\subsection{Nantucket's "Links" Golf Course}

When establishing feasibility it is often useful to choose a model to examine in order to aid in the decision making process. The goal would be to find a golf course 
that is operating under similar conditions to what is being proposed on Block Island, namely a nine hole golf course that is relatively isolated from the majority of competing courses. Nantucket's Miacomet Golf Course is probably the best model course to examine.

Miacomet is a nine hole daily fee, "links" style course that originally operated under private ownership. Nantucket's Land Bank, concerned that the course could be lost to residential development, decided to acquire the property when it was put up for sale in 1985. Using the Revenue Bond financing option, they were able to acquire the Miacomet, and are currently leasing the property to a group who manage the golf property. The lease revenues are used to pay off part of the bond with the rest coming from Land Bank resources.

According to the Land Bank, the course is operating very successfully, and there are even plans to expand the course to eighteen holes. Although there are other courses on the Island, Miacomet has found its niche as an affordable, no frills course that provides a good round of golf for residents and tourists alike (Nantucket Land Bank, 1991).

Like Block Island, many residents on Nantucket worry about pesticide and fertilizer residues contaminating water resources on the Island. Miacomets rugged "links" design means that less fertilizers and pesticides are applied to the golf course. The course has a rough unkempt look and the greens are not terribly fast, but the course receives adequate play and provides residents and tourists with an enjoyable and affordable round of golf. The number of rounds being played annually was 
unavailable, but with nine more holes being proposed, it is obvious that Miacomet is operating profitably.

Even with Nantucket's two other golf courses, Miacomet has been able to operate profitably since being purchased by the Land Bank. This no frills basic "links" concept is an excellent model that fits closely with Block Island's rural seaside character. The scenarios are startlingly similar. Nantucket's environment and tourist economy are very similar to Block Island's. The Miacomet model helps prove that golf can operate profitably under isolated Island conditions. Unlike Nantucket, Block Island currently has no golf course. The potential for success is probably greater than Miacomet's since no other golf competition would exist on Block Island. This model helps strengthen the argument that golf can be profitable for Block Island.

\subsection{Golf Course Cost Estimates}

Golf courses invariably are expensive to build. Costs vary, but it is not unusual to see 3 to 5 million dollars spent to construct and establish a typical 18 hole golf course (American Society of Golf Course Architects, 1989).

Block Island would most likely only be able to construct a nine hole golf course, but a significant monetary commitment would be required nevertheless. The two sites proposed on the Island have dissimilarities that would mean different costs in

development. The Northern proposal would be less expensive to develop due to the fact that less vegetation removal would be required and it is very likely that minimal topographic alterations would be needed on the Northern site. Cost estimates for 
both the Northern and Southern sites can be seen in Table 9.

\subsubsection{Revenues and Expenditures}

Revenues and expenditures for the proposed course are important to examine in order to help determine the costs involved in the annual operation of the golf course. A five year schedule is the norm for a revenues and expenditures analysis. Table $1 \mathrm{C}$ shows expected revenues and expenditures for a golf course facility on Block Island. A variety of sources were utilized to aid in the quantification of costs for course development, projected revenues and projected expenses. 


\section{TABLE 9 COST ESTIMATE FOR BLOCK ISLAND GOLF COURSE DEVELOPMENT}

\begin{tabular}{|c|c|c|}
\hline COST ELEMENT & NORTHERN SITE & SOUTHERN SITE \\
\hline $\begin{array}{l}\text { Wells and Monitoring* } \\
\text { Golf Course Construction** } \\
\text { Clubhouse } \\
\text { Maintenance Building } \\
\text { Cart Storage } \\
\text { Miscellaneous ( } 5 \% \text { of Total) }\end{array}$ & $\begin{array}{l}\$ 5000 \text { per well } \\
\$ 1,000,000 \\
\$ 175,000 \\
\$ 200,000 \\
\$ 30,000 \\
\$ 72,750\end{array}$ & $\begin{array}{l}\$ 5000 \text { per well } \\
\$ 1,100,000 \\
\$ 175,000 \\
\$ 200,000 \\
\$ 30,000 \\
\$ 77,750\end{array}$ \\
\hline $\begin{array}{l}\text { Bubtotal } \\
\text { Contingency } 10 \%\end{array}$ & $\begin{array}{l}\$ 1,527,750 \\
\$ 152,775\end{array}$ & $\begin{array}{l}\$ 1,632,750 \\
\$ 254,362\end{array}$ \\
\hline Total construction & $\$ 1,680,525$ & $\$ 1,796,025$ \\
\hline $\begin{array}{l}\text { Equipment (Golf Maintenance) } \\
\text { Golf Car Lease ( } 25 \text { cars) } \\
\text { Maturation } \\
\text { Architects Fees } \\
\text { other Fees }\end{array}$ & $\begin{array}{l}\$ 150,000 \\
\$ 22,500 \\
\$ 110,000 \\
\$ 125,000 \\
\$ 50,000\end{array}$ & $\begin{array}{l}\$ 150,000 \\
\$ 22,500 \\
\$ 110,000 \\
\$ 125,000 \\
\$ 50,000\end{array}$ \\
\hline subtotal & $\$ 457,500$ & $\$ 457,500$ \\
\hline PROJECT TOTAL & $\$ 2,138,025$ & $\$ 2,253,525$ \\
\hline
\end{tabular}

Sources: National Golf Foundation, American Society of Golf Course Architects, Golf Course Superintendents Association of America. 
TABLE 10

\section{PROJECTED REVENUES AND EXPENDITURES FOR BLOCK ISLAND GOLF COURSE}

Year 1 Year

Year 3

Year

Year 5

REVENUES :

Greens Fees

Cart Rental Fees

Golf shop Sales

Total Revenues:

EXPENDITURES:

Wages

Maintenance

Cart Lease

clubhouse

Total Expend.:

Net op. Income:

Debt Service:

Profit (Loss)

After Debt Serv
$\$ 182,000$

$\$ 117,600$

$\$ 27,300$

$\$ 326,900$

$\$ 208,000$

$\$ 134,400$

$\$ 31,200$

$\$ 373,600$
$\$ 252,000$
$\$ 162,000$

$\$ 37,800$

$\$ 451,800$
$\$ 300,000$

$\$ 180,000$

$\$ 45,000$

$\$ 352,000$

$\$ 211,200$

$\$ 52,800$

$\$ 525,000 \$ \$ 16,000$

Cumulative Debt

Service:

$$
\begin{array}{r}
\$ 135,000 \\
\$ 65,000 \\
\$ 22,500 \\
\$ 20,000 \\
\$ 242,500 \\
\$ 84,400 \\
\$ 153,000
\end{array}
$$

$\$ 148,837$

$\$ 71,662$

$\$ 156,278$

$\$ 75,245$

$\$ 26,046$

$\$ 23,625$

$\$ 24,806$

$\$ 23,152$

164,091

$\$ 22,050$

$\$ 280,721$

$\$ 79,007$

$\$ 27,348$

$\$ 254,625$

$\$ 267,355$

$\$ 294,655$

$\$ 118,975$

$\$ 184,445$

$\$ 244,279$

$\$ 321,345$

$\$ 153,000$

$\$ 153,000$

$\$ 153,000$

$\$ 153,000$

$(\$ 68,600)$

$(\$ 34,025)$

$\$ 31,445$

$\$ 91,279$

$\$ 168,345$

$(\$ 68,600)(\$ 102,625)(\$ 71,180) \quad \$ 20,099$

Source: National Golf Foundation, American Society of Golf course Architects, Golf Course Superintendents Association of America. 


\subsubsection{Financial Conclusions}

Results indicate that the course would generate a profit by the fourth year of its operation. This model is based on the a Revenue Bond option in which a Debt Service would need to be paid annually. The model also assumes that the land is not purchased, but received by land donation or grant. Purchasing the land outright would be too expensive and would make the project an unprofitable venture.

An examinatic.l of the assumptions show conservative estimates in regards to number of rounds played ( $25 \%$ of golfing tourists). If an aggressive advertising campaign that utilized hotels offering golf packages were utilized, the number of rounds could potentially be higher than those projected in the model (perhaps as high as $40 \%$ to $45 \%$ ). A nine hole golf course is capable of carrying 40,000 rounds per year, therefore 30,000 rounds at maturity of the golf course could be a realistic possibility.

\subsection{Other Economic Issues}

\subsubsection{Attracting Golf Tourism to Block Island}

A Successful golf course on Block Island is contingent upon its ability to attract an adequate number of golfers to the Island during both the summer and shoulder seasons. Growth in golf participation is the key. Attracting golfers, especially during the shoulder season would raise the number of rounds played anually, thus increasing profit potential. Not only would the golf course reap the benefits of added revenue, but hotels, inns, retaurants and other groups would find financial gain from a busier 
shoulder season as well.

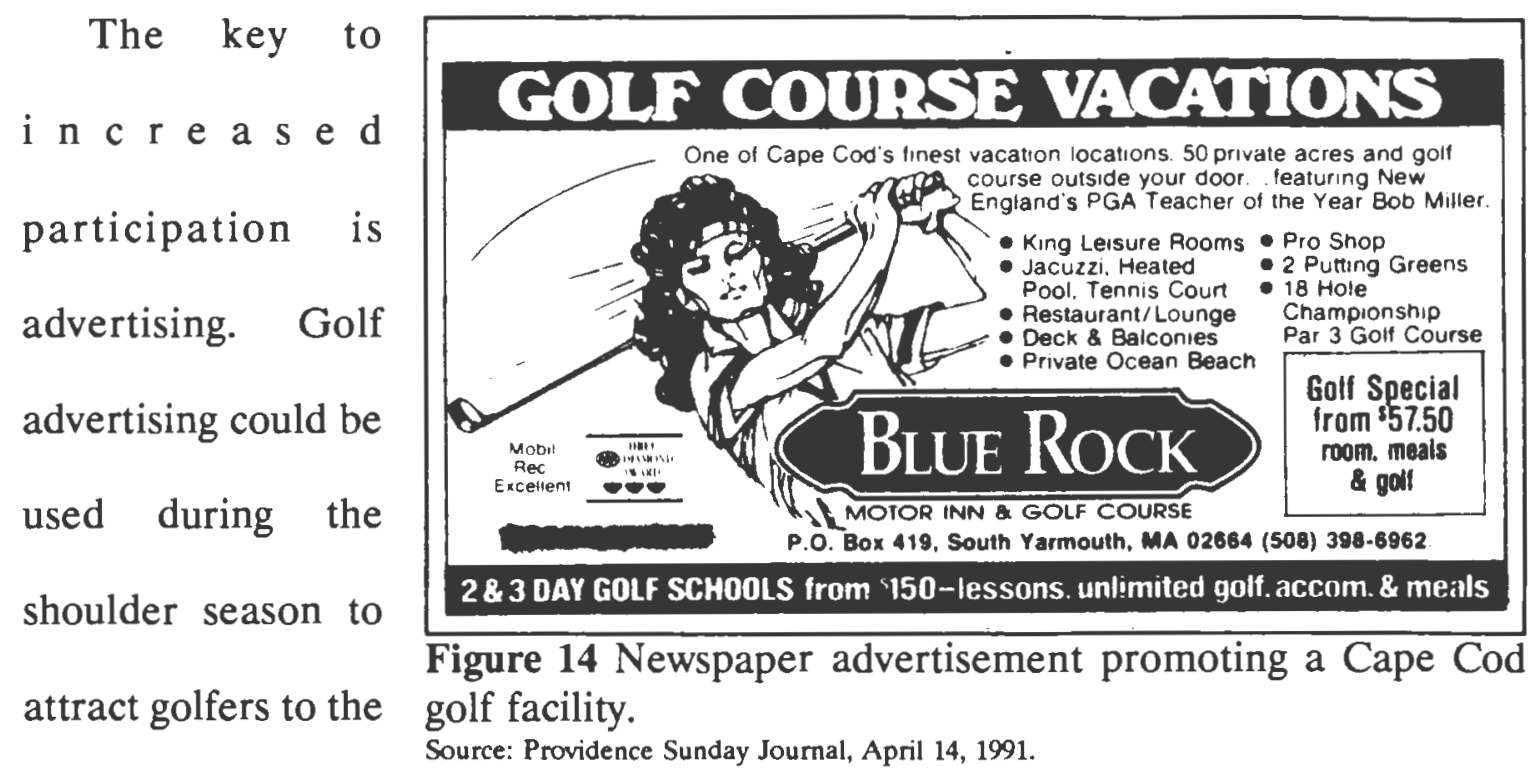

Island. Newspaper

or radio advertising could provide exposure that would entice players from the mainland to try a round at the Block Island course. Reviews by golf magazines and other periodicals could also improve overall exposure of the course. The unique playing characteristics along with the reputation of the Island as a resort area could work to attract a large number of players.

Hotels on Cape Cod advertise heavily in New England newspapers, offering golf/lodging packages that attract golfers from throughout New England (See Figure 14). This method could be utilized on Block Island as well. Special golf packages arranged between the golf course and hotels and inns on the Island could be devised. The results would mean profit for both the golf course and hotel owners alike, not to mention additional employment opportunities for the residents of the Island.

Advertising then, is the key to providing regionwide exposure for the new golf 
course. Making people know a golf course exists on Block Island is the first step to attracting them. Once people know a challenging and unique course exists on the Island, they will begin to come in greater numbers, thus improving the golf courses profit potential.

\subsubsection{Transportation}

Many golfers who come to the Island will not be bringing their cars along with them. Bicycles and mopeds are not useful since it would be difficult to carry clubs while riding. The only group that would probably use cars to get to the golf course would be year the round and seasonal residents of the Island. All others would require taxi or shuttle services in order to get to and from the golf course.

Block Island's larger hotels and inns could possibly provide shuttle services to potential golfers, but insurance costs make the proposition an expensive option. It would probably be more effective to develop an agreement with the Island's Taxi Commission.

According to the Block Island Taxi Commission, there are 34 registered taxi's that operate on the Island between May 14 and December 18 (Block Island Taxi Commission, 1991). The Commission has plans to acquire 12 , nine passenger vans to improve Island wide taxi services. The addition of these vans would aid in the shuttling of golfers to and from a golf course facility.

Marilyn Wolfe, chairperson of the Taxi Commission, feels that the current taxi service could adequately shuttle the golf population during not only the summer 
season, but the shoulder season as well. The addition of the vans would only improve their ability to service the golf population. She recommends the use of Citizens Band radios in hotels and inns in order to maintain direct contact with taxi operators on the Island.

Hotel operators have stated that taxi service needs improvement, especially during the slower shoulder season. The attraction of shoulder season play is critical to adding tourist income, and taxi services would need to be as efficient during this period, as they are during the busier summer season. A dispatch system using CB's could possibly be the answer to providing prompt taxi service to golf tourists.

Providing prompt, efficient service throughout the golf playing season is of paramount importance to the success of golf on Block Island, and hotels and the Taxi Commission will need to work together to devise the best method of shuttling golfers to and from the course effectively.

A golf taxi dispatch system would need to be devised for day tripper golfers arriving on the ferry. Perhaps an information sign providing a taxi dispatch telephone number for golfers could be set up somewhere near the ferry area. Potential golfers could call this number to arrange taxi services to the course. This issue as well, would require a plan devised by the Taxi Commission.

\subsubsection{Employment Possibilities}

The potential golf course has the potential to provide a number of primary employment opportunities. Golf maintenance would require four to six seasonal 
employees and perhaps two full time positions. Depending on the type of clubhouse designed, 4 to 6 employees are a possibility. Caddying would also provide employment opportunities for youth on the Island. Secondary employment that could be generated as a result of the golf course would include the necessity for additional staff within hotels during the shoulder season. Additional taxi hours would be generated as a result of the golf course. In short, tourism related employment that has not been utilized during shoulder season months previous to golf course development, could now extend into these months, thus providing additional employment opportunities in the future.

\subsubsection{Dealing With Additional Tourists}

Many concerns in the Block Island Golf Course Study Committee Survey voiced the opinion that a golf course could generate excessive tourist populations. This is partially true, but since many of these tourists will be playing golf their presence would be isolated to the golf course during at least a portion of their stay. Most importantly they would generally be spending their time away from the busy downtown area, where most of the tourist population tends to concentrate.

Additional shoulder season golfers will not be a major concern, since tourist populations tend to be much lower during these months and any additional tourist arrivals would undoubtedly be welcomed by hotel and restaurant owners as well as other groups who would benefit from additional tourism during these months. 


\subsection{Findings}

The results of the financial assessment show the following:

1. Ownership and Financing Options- A variety of finance options are available, depending on who develops the course. The use of General Obligation or Revenue Bonds would be best recommendation for financing the golf course. Municipalities can usually receive handsome interest rates when Bond options are used. Privately owned daily fee courses may wish to choose conventional loan options in the development of the course.

2. Golf Course Model- Miacomet golf course, on Nantucket, operates successfully under conditions that would be considered similar to Block Island. Additionally Miacomet's links design fits in well with the character of the Island and uses less pesticides and fertilizers than conventional golf courses.

3. Golf Course Estimates- Costs of construction and development of the course would probably fall in the range of 2 million dollars based on conservative estimates for golf development. This is within a reasonable range for the development of a typical nine hole course.

Revenue and expentiture analysis show that the course could generate a profit by the fourth year, based on a conservative number of rounds being played in the first five years. Good advertising and high turnout for golf play once the course has been discovered, could mean that the course could potentially return a profit by the third year of operation. 
4. Other Economic Issues- Advertising through a variety of medias is the key to increasing the number of rounds generated at the golf course. Golf course packages utilizing hotel and inns could attract golfers during the shoulder months. Cape Cod's aggressive advertising style could be a model for Block Island's golf course.

Transportation to the golf course could be 'andled by the Island's taxi's, provided an adequate system can be worked out between the taxi commission and the various hotels and inns on the Island. The use of Citizens Band Radios could be the answer to providing efficient service.

The golf course will provide additional employment in the form of golf course personnel, and additional tourist related employment during the shoulder months (ie. hotel and restaurant employment).

Additional tourists generated by the course would probably not impact the area negatively since most of thes tourists would be confined to the golf course, which is located a substantial distance from the downtown area. 


\section{REFERENCES FOR CHAPTER FIVE}

American Society of Golf Course Architects; Guidelines For Planning and Developing A Public Golf Course, Jupiter Florida; National Golf Foundation, 1989.

Phillips, Patrick L. Developing with Recreational Amenities, The Urban Land Institute, Washington, DC, 1987.

Veri, Albert and Associates; Feasibility Report: Ninigret Park Municipal Golf Course, April 24, 1990. 
APPENDICES 


\section{APPENDIX A}

\section{BLOCK ISLAND GOLF COURSE STUDY COMMITTEE SURVEY RESULTS}

In September of 1990 the Block Island Golf Course Study Committee conducted a non scientific survey to determine if the concept of a golf course of some type would be well accepted by the full time and part time residents of the Island. The Committee placed a survey question sheet in the September issues of The Block Island Times and asked a variety of questions that would provide the Committee with a general impression of public opinion on the concept of golf on Block Island. The general goal of the survey was to determine if it would be prudent to make a concerted effort to bring golf to the Island.

Although nonscientific, it provided some interesting results that can prove to be very useful in assessing public opinion. In addition the survey asked for written comments from the person filling in the survey. These comments can prove to be very useful as well. The general results of the survey can be seen below. Part I is the general answer section, while Part II examines the written comments that were given by the various individuals filling out the survey:

\section{PART I GENERAL ANSWER SECTION}

Question 1. Further study should continue on the feasibility of a golf facility on Block Island.

Strongly Agree---- $42 \quad 61$

Agree----------- 19

Undecided--------- 5

Disagree--------- $6 \quad 22$

Strongly Disagree- 16 
Question 2. Outcome of establishing a golf facility on Block Island's economy and atmosphere.

Strongly Enhance-- $24 \quad 44$

Enhance---------- 20

Undecided-------- 16

Detract-----.-.-. $10 \quad 16$

Strongly Detract-- 6

Question 3. * Development of Golf Facility

Town Owned, Town Operated-----------.--- 14

Privately Owned Privately Operated---.--...-.. 11

Town Owned, Leased to a Golf Management Group- 50

Question 4. * Environmental Concerns (check all that apply)

Constructive Use of Open Space---:--.------- 56

Concerns with Use of Pesticides and Fertilizers- 43

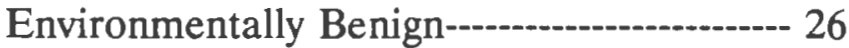

Question 5. * Supplemental Facilities Desired

Clubhouse------.-. 39

Restaurant--.----- 25

Driving Range----- 29

Tennis Courts----- 19

Miniature Golf---- 11

Question 6. * Golf Facility's effects on tourism (check all that

Tourist Oversaturation Would Result----- 10

Overall Island Economic Boost--..--.---- 37

Shoulder Season Boost---:------.------ 39

PART II COMMENTS AND CONCERNS (written comments are in no particular order)

- Don't bother if it's all par 3's.

- It would be a big plus as far as our family is concerned.

- Frankly, it might upgrade the level of the average Block Island tourist. 
- Even just a nice nine hole course would be a pleasant asset to the island. I would certainly use it and spend more time here in summers, most likely.

- I think it is the one amenity that is needed to make the Island a more attractive nine month destination.

- I strongly oppose a town financed golf course.

- This is totally out of character with what I now love about Block Island.

- We are not golfers but the island needs another draw, particularly to increase tourism during the beautiful fall months.

- Block Island would benefit greatly from a golf course.

- I think it would help the off season the most.

- This would serve islanders and tourists alike.

- $\quad$ Go for it.

- A golf course wouls add another enjoyable vacation activity, although we would still vacation on Block Island, regardless.

- I don't know of any golf course that was a detriment to a town, all are considered assets.

- Totally out of character with Block Island.

- We've had friends interested in buying, but don't do so because there is no golf.

- Let's concentrate on what we have already.

- Incompatable with Block Island landscape.

- What a great way to save open space on Block Island.

- It goes against the grain. Please don't force it.

- Use of golf course would not justify cost and expense of running. We need the open space for more productive ventures, animal pasture, bikeways and walkways. 
- Will not do anything for tourism and will only raise costs to taxpayers.

- The island is not a place for a golf course. People that visit and residents enjoy the Island because its unique not commercialized.

- Additional visitors attracted will not be harmful.

- Great for year round residents.

- Would be great recreation for island people.

- Islanders should get first shot for golf time.

- There should be a protection of views.

- Any recreational improvements is apt to increase tourist activity, in this case I think only slightly, but may provide income to the town from many who are here already.

- The whole idea sounds ridiculous! Where are you going to get the land. I thought we wanted open space not driving ranges that do not harbor wildlife.

- Perhaps there are more important things that should be considered first, such as the bike paths that are already funded.

- Water supply, need lots for a golf course and Island may have problem.

- Just a golf course, no restaurant or anything like that.

- $\quad$ Ridiculous idea.

- Its time to get on with what would be a tremendous economic opportunity.

- Not really enthusiastic about this.

- No good effects. Out of character for Block Island.

- Totally unnecessary, we don't need it.

- Act now!

- Totally inappropriate.

- Will golfers shoo walkers away, Will general public lose access top open space 
lands.

- Let's keep golf in more appropriate surroundings.

- Would love a course for islanders. Do not wish to attract tourists who only come to the Island to play golf.

- No tourists- Be careful and control memberships.

- Block Island does not need a golf course for economic boon.

- This is a waste of time, money, and energy.

- $\quad$ Please drop the idea, we do not need it.

- We do not feel that golf will be a drawing card but an added enhancement. 


\section{APPENDIX B \\ GOLF COURSES CONTACTED FOR DEMAND ANALYSIS}

In order to gain a general impression of golf demand in southern Rhode Island, a number of course were contacted to determine approximately the number of

rounds played at their courses, as well as the length of time an average golfer had to wait on wekends. The survey was informal and most course were only able to estimate their rounds, but most reported rounds approaching 40,000 rounds per year and $21 / 2$ to 3 hour waits on weekends. The following courses were contacted:

1. Laurel Lane Golf Course, South Kingstown Rhode Island.

2. Exeter Country Club, Exeter, Rhode Island.

3. Jamestown Country Club, Jamestown, Rhode Island.

4. Woodland Greens Golf Course, North Kingstown, Rhode Island. 


\section{APPENDIX C}

\section{KEY INFORMANT INTERVIEWS}

The following key informants were contacted through either telephone coversations or personal interviews:

Contact Date

1. Ms. Martha Ball, Town of New Shoreham

$4 / 18 / 91$

2. Ms. Pam Boul, Block Island Chamber of Commerce

$4 / 18 / 91$

3. Ms. Dawn Darbey, Nantucket Land Bank

$4 / 23 / 91$

4. Mr. Robert Downey, Block Island Historian

$4 / 18 / 91$

5. Ms. Rita Draper, Manager of 1661 and The Manisees Inn

$4 / 18 / 91$

6. Mr. Vincent McAloun, Manager of the Blue Dory Inn

$12 / 11 / 90$

7. Mr. Robert Schleimer, Owner, New Shoreham House

$4 / 18 / 91$

8. Mr. Edward Smith, Manager of the National Hotel

$4 / 18 / 91$

9. Mr Joseph Sprague, Director, Rhode Island Golf Association 3/21/91

10. Mr. Michael Weremay, Vice President, Gates, Leighton and Associates, Inc.

$2 / 15 / 91$

11. Ms. Marilyn Wolfe, Chairman, Block Island Taxi Commission 4/18/91 
